\title{
Review of the millipede genus Levizonus Attems, 1898, with description of a new species from the Far East of Russia (Diplopoda, Polydesmida, Xystodesmidae)
}

\author{
Elena V. MIKHALJOVA \\ Federal Scientific Center of the East Asia Terrestrial Biodiversity, Far Eastern Branch \\ of the Russian Academy of Sciences, Vladivostok 690022, Russia. \\ E-mail: mikhaljova@biosoil.ru \\ (1) https://orcid.org/0000-0001-7132-8677 \\ urn:lsid:zoobank.org:author:C7962B1F-80FD-4330-AF41-C17B7EA0214C
}

\begin{abstract}
The genus Levizonus Attems, 1898 is rediagnosed and shown to contain eight species from Russia (Far East), North Korea, Japan and North-East China. One species is described here as new to science: Levizonus nakhodka sp. nov. A new formal synonym is proposed: Levizonus circularis Takakuwa, 1942 = Levizonus variabilis Lokschina \& Golovatch, 1977 syn. nov., the valid name being the former. Levizonus circularis Takakuwa, 1942 is recorded for the fauna of China for the first time. All currently known species of Levizonus are included in a key, mapped and discussed.
\end{abstract}

Keywords. Key, distribution, eastern part of Asia.

Mikhaljova E.V. 2021. Review of the millipede genus Levizonus Attems, 1898, with description of a new species from the Far East of Russia (Diplopoda, Polydesmida, Xystodesmidae). European Journal of Taxonomy 751: 159184. https://doi.org/10.5852/ejt.2021.751.1387

\section{Introduction}

The millipede genus Levizonus Attems, 1898 has hitherto been known to be represented in Russia (Far East), Korea and Japan by eight species: L. circularis Takakuwa, 1942; L. distinctus Mikhaljova, 1990; L. laqueatus Mikhaljova, 1981; L. malewitschi Lokschina \& Golovatch, 1977; L. montanus (Takakuwa, 1941); L. takakuwai (Verhoeff, 1941); L. thaumasius Attems, 1898 and L. variabilis Lokschina \& Golovatch, 1977. This genus was first erected as a subgenus of the genus Sulciferus Attems, 1898, based on the single species Sulciferus (Levizonus) thaumasius, taken from Vladivostok, Russia (Attems 1898). However, later Attems used Levizonus as a generic name (see Attems 1931, 1938). About 80 years later, other species of this genus were described from the Far East of Russia (Lokschina \& Golovatch 1977; Mikhaljova 1981a, 1990). One of these species (L. orientalis Lokschina \& Golovatch, 1977) was found to be a junior subjective synonym of L. thaumasius (see Golovatch 1979). Tanabe (1994) revised the Japanese millipedes of the genus Levizonus. 
The present study is a review of the genus Levizonus, based not only on new material, but also on the old specimens. As a result, one previously described species (L. variabilis) is synonymized and one new species is added. In addition, a key is given to all currently known species of Levizonus and their distributions are mapped and discussed.

\section{Material and methods}

Material treated here has been deposited in the collection of the Federal Scientific Center of the East Asia Terrestrial Biodiversity, Far Eastern Branch of the Russian Academy of Sciences, Vladivostok, Russia (FSCB); a few paratypes have been transferred to the Zoological Museum, State University of Moscow (ZMUM), as indicated in the text. Some of the previously published material was re-examined. Specimens were preserved in $70 \%$ ethanol. In the process of studying the material, the gonopods and some other parts were dissected from a limited number of males and females and mounted in glycerin as temporary micro-preparations. Specimens were studied and illustrated using standard stereomicroscopic, photographic and drawing equipment. SEM micrographs were prepared at the Centre of Collective Use 'Biotechnology and Gene Engineering' of the Federal Scientific Center of the East Asia Terrestrial Biodiversity, Far Eastern Branch of the Russian Academy of Sciences in Vladivostok, using a Zeiss Evo 40 scanning electron microscope. Mounts for SEM were made by air-drying after transfer to acetone via $96 \%$ ethyl alcohol, mounting on stubs, and coating with chromium. After examination, SEM material was removed from stubs and returned to alcohol. Some colour photographs (Fig. 1A-B) were prepared using a stereo-microscope (Olympus SZX16) and a digital camera (Olympus DP74), and stacked using Helicon Focus software. SEM images were processed in Adobe Photoshop.

The family-level classification adopted here is that of Shelley (2003). The genus-level classification adopted here is that of Hoffman (1980).

\section{Abbreviations}

FSCB = Federal Scientific Center of the East Asia Terrestrial Biodiversity, Far Eastern Branch of the Russian Academy of Sciences

$\mathrm{H} \quad=$ Horn

$\mathrm{K}=$ Knee-shaped outgrowth

$\mathrm{K} 1=$ Not knee-shaped outgrowth

$\mathrm{P} \quad=$ Arcuate protrusion

$\mathrm{SL} \quad=$ Solenomere

ZMUM = Zoological Museum, State University of Moscow

\section{Results}

\section{Taxonomy}

Class Diplopoda de Blainville in Gervais, 1844

Order Polydesmida Pocock, 1887

Suborder Leptodesmidea Brölemann, 1916

Superfamily Xystodesmoidea Cook, 1895

Family Xystodesmidae Cook, 1895

Genus Levizonus Attems, 1898

Sulciferus (subgenus Levizonus) Attems 1898: 346, 351.

Levizonus Attems 1931: 69 (full genus). 

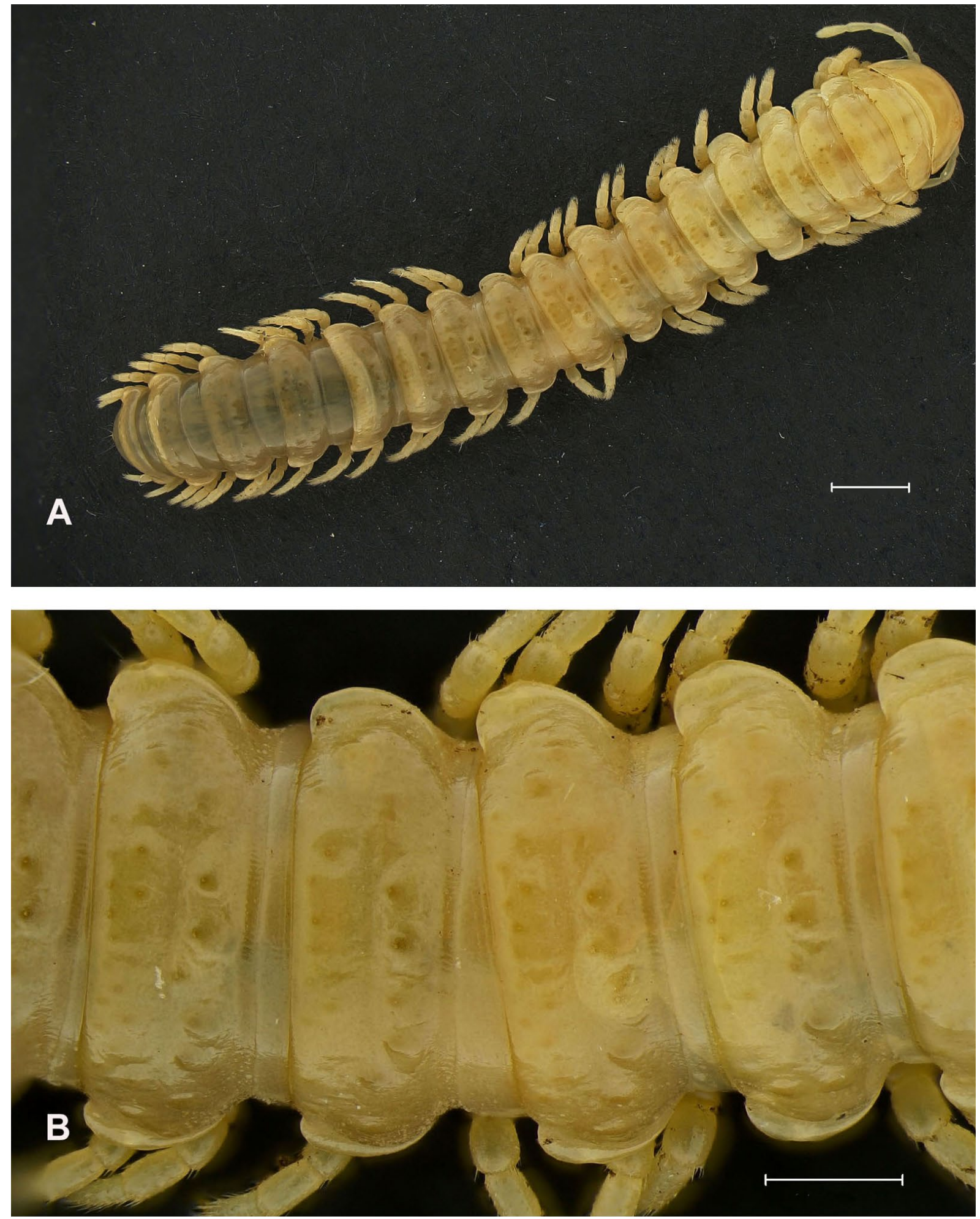

Fig. 1. Levizonus circularis Takakuwa, 1942, §, from Russia (FSCB 142005). A. Habitus, dorsal view. B. Midbody rings, dorsal view. Scale bars: $\mathrm{A}=2 \mathrm{~mm} ; \mathrm{B}=1 \mathrm{~mm}$. 
Ezaria Takakuwa, 1941: 8 (type species Ezaria montana Takakuwa, 1941, by monotypy; synonymized by Hoffman 1980).

Profontaria Verhoeff, 1941: 411-412 (type species Profontaria takakuwai Verhoeff, 1941, by monotypy; synonymized by Tanabe 1994).

Hokkaidaria Verhoeff, 1941: 414-415 (invalidly proposed without type species).

Ezodesmus Takakuwa, 1942: 42 (type species Ezodesmus lunatus, Takakuwa, 1942, by monotypy; synonymized with Profontaria by Hoffman 1956, synonymized with Levizonus by Tanabe 1994).

Levizonus - Attems 1938: 173. - Takakuwa 1954: 73. - Jeekel 1971: 270. - Hoffman 1980: 157. — Shelley 1993: 1163. — Tanabe 1994: 102; 2002: 2176. — Tanabe \& Shinohara 1996: 1470. — Shelley et al. 2000: 104. — Mikhaljova 2004: 243; 2017: 293. — Korsós et al. 2011: 55. — Marek et al. 2014: 71. — Tanabe \& Sota 2014: 442. — Minelli 2015: 400.

Ezaria - Takakuwa 1954: 87. — Miyosi 1959: 82. — Jeekel 1971: 264. - Hoffman 1980: 157. — Tanabe 1994: 102.

Ezodesmus - Takakuwa 1954: 85. — Jeekel 1971: 264. - Hoffman 1980: 157. — Tanabe 1994: 102.

Profontaria - Hoffman 1956: 99; 1980: 157. — Miyosi 1959: 82. — Jeekel 1971: 282. — Tanabe 1994: 102. - Shelley et al. 2000: 104.

Hokkaidaria - Jeekel 1971: 266. — Hoffman 1980: 157. — Tanabe 1994: 102

\section{Included species}

L. circularis Takakuwa, 1942 (= L. variabilis Lokschina \& Golovatch, 1977, syn. nov.)

L. distinctus Mikhaljova, 1990

L. laqueatus Mikhaljova, 1981

L. malewitschi Lokschina \& Golovatch, 1977

L. montanus (Takakuwa, 1941)

L. nakhodka sp. nov.

L. takakuwai (Verhoeff, 1941)

L. thaumasius Attems, 1898

\section{Type species}

Levizonus thaumasius Attems, 1898, by original designation.

\section{Diagnosis}

Differs from other Palearctic xystodesmid genera mainly by the circular, arcuate to coiled ring-like (one ring vs 1.5 to 2 rings in Parafontaria Verhoeff, 1936) slender, uniramous gonopod telopodite without prefemoral process (as in Parafontaria), but with a modified apex; by relatively long subcylindrical gonopod coxa (vs oval in Parafontaria), and a short SL (Figs 5A, 8C) (as in Parafontaria but vs long in Riukiaria Attems, 1938).

\section{Description}

\section{Male}

CoLour. Ventral and lateral body parts yellow-white. Tergites often with a brown pattern (Fig. 12).

HEAD. Smooth, setose frontally, more densely so at external margin, with $2+2$ vertigial setae and lateral excavation for accommodation of antennae. Epicranial suture distinct. Antennae slightly clavate, with four apical cones.

ColLum. Ovoid, considerably broader than head but somewhat narrower than ring 2. 
BoDy. Stout, with 20 rings including telson. Metaterga moderately convex, without setae. Transverse metatergal sulcus absent but metaterga with a shallow transverse medial depression. Dorsal surface of metazona shining and smooth excluding $L$. circularis ( $=$ L. variabilis syn. nov.), with transverse rows of low bosses on metaterga. Paraterga relatively well developed, with narrow peritremata (calluses). Paraterga thin on rings $1-4$, thicker on more posterior rings. Anterior angles of paraterga rounded, posterior angles rounded, becoming somewhat elongated though never clear-cut on posterior half of body. Pore formula normal. Pleurites finely granular. Sternites with two small outgrowths between leg pair 3 and leg pair 4 .

Telson. Caudal dorsal projection weakly conical. Anal valve with two setae at a bolster-shaped mesal edge. Subanal scale subtriangular, with $1+1$ setae.

LEGS. Relatively long but stout, increasingly strong in anterior part of body. Coxa and prefemur (either only prefemur or only coxa) of all postgonopodal legs (or only hind legs) distoventrally with a small short outgrowth becoming longer posteriorly toward telson. Coxa 2 with a large setose outgrowth terminating the vas deferens.

GoNOPODS. Gonopodal opening pear-shaped. Gonopods in situ held parallel to each other. Coxa relatively long, slender, subcylindrical, not fused medially, with strong setae distally (Figs 5C, 6A, 7A, 9A, 10A). Sternal apodeme and coxa subequal in length. Telopodites slender, arcuate to coiled and ring-like (one ring), unipartite, gutter-shaped, tapering distally or subparallel-sided, with or without longitudinal flange on inner surface, with a modified apex. Prefemoral process absent. Prefemur with a small lateral outgrowth basally only. Border between acropodite and prefemur indistinct. Distal part of acropodite with an external short process $(=\mathrm{SL})$ terminating the seminal groove (Figs 5D, 8C, 10B).

\section{Female}

BoDy. Usually stouter than in male. 20 rings including telson.

Legs. Usually slenderer than in male. Coxa 2 with a small, setigerous process. Sternites with two tiny outgrowths between leg pair 3 only.

Vulvae. Setose. Bursa composed of two valves, operculum, one setose receptacle. Valves almost identical in size and shape.

\section{Distribution}

Russia (Far East: Primorskiy krai), North Korea, Japan (Hokkaido), North-East China.

\section{Levizonus circularis Takakuwa, 1942}

Figs $1-3,13$

Levizonus circularis Takakuwa, 1942: 43-44, 44, fig. 8 (holotype or lectotype not designated; number of specimens in the type series unclear; location of types is unknown; type locality: Sangnam-ri, North Korea).

Levizonus variabilis Lokschina \& Golovatch, 1977: 76-77, fig. 3 (holotype $\widehat{\partial}$, from Olenevod, Lazovskiy District, Primorskiy krai, Russia, in ZMUM). Syn. nov.

Levizonus circularis - Takakuwa 1954: 74-75, 74, fig. 79. — Paik 1958: 362. — Golovatch 1979: 17. — Mikhaljova et al. 2000: 117. — Marek et al. 2014: 72.

Levizonus variabilis - Lokšina \& Golovatch 1979: 385. - Kurcheva \& Mikhaljova 1980: 120. — Mikhaljova 1981a: 64, figs 2, 4, map (fig. 5); 1981b: 87; 1983: 81; 1990: 136; 1993: 34; 1998: 55, figs 218-223, map 12; 2004: 251, figs 638-650, map 32; 2009a: 5; 2009b: 394; 2017: 301, figs 685-697, map 43. — Mikhaljova \& Petukhova 1983: 53. — Ganin 1997: 124; 2009: 153; 2011: 341. - Tanabe 1994: 108; 2002: 2178. 

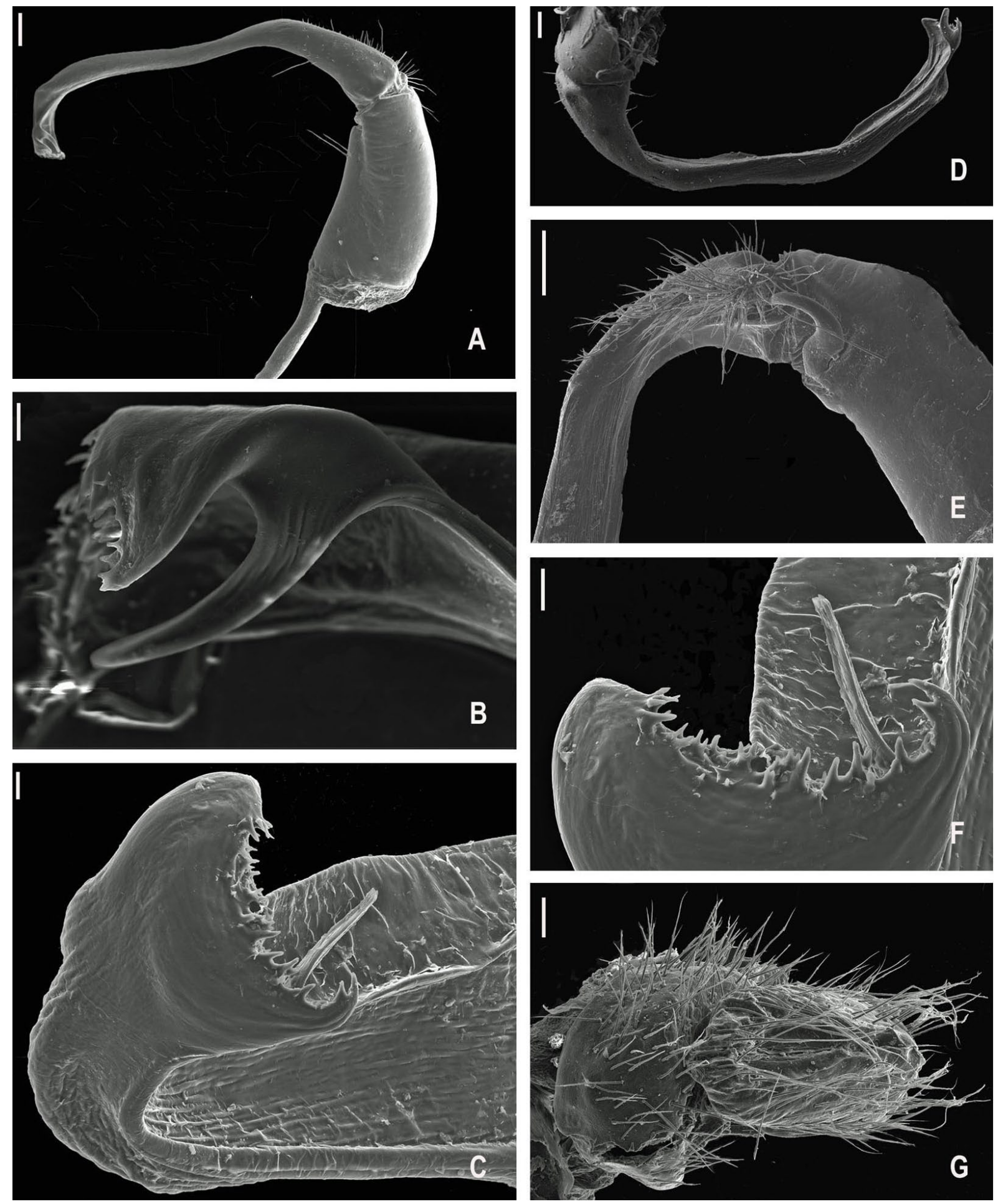

Fig. 2. Levizonus circularis Takakuwa, 1942, $\widehat{\partial} \hat{\partial}$,, , from China (FSCB 12019Ch) (A-B) and Russia (FSCB 232008, 212008) (C-G). A. Gonopod, lateral view, longitudinal striae are not visible. B. Gonopod apex, lateral view. C, F. Gonopod apex, ventral view. D. Gonopod, lateral view, coxite partially destroyed. E. Middle part of gonopod, mesal view. G. Vulva, mesal view. Scale bars: A, E = $200 \mu \mathrm{m}$; $\mathrm{D}, \mathrm{G}=100 \mu \mathrm{m} ; \mathrm{B}-\mathrm{C}, \mathrm{F}=20 \mu \mathrm{m}$. 


\section{Diagnosis}

The main distinguishing characters of the species are as follows: apex of gonopod telopodite (Fig. 2C) not like two plates placed perpendicular to each other as in L. malewitschi; gonopod SL, more or less strongly curved mesad (vs not strongly curved mesad in other congeners); the central edge of the gonopod telopodite apex with outgrowths and spinules (Fig. 3A-D) (vs without outgrowths and spinules in other congeners excluding L. thaumasius, L. nakhodka sp. nov. and L. malewitschi); metaterga with low bosses either everywhere (Fig. 1) or only laterally (vs smooth in other congeners).

\section{Material examined}

RUSSIA 1 1 (holotype of Levizonus variabilis; unfortunately, the holotype is devoid of gonopods); Primorskiy krai, Lazovskiy District, Olenevod; 14 Sep. 1968; L.S. Shvetsova leg.; ZMUM 1912 • 1 O; Primorskiy krai, Lazovskiy State Nature Reserve, Zvyozdochka Cordon; 8 Jun. 1979; E.V. Mikhaljova leg.; valley of stream, litter; FSCB $11979 \bullet 3 \hat{\delta} \widehat{\delta}, 3$ 우; same locality as for preceding but Quercus forest on the coast near Petrova

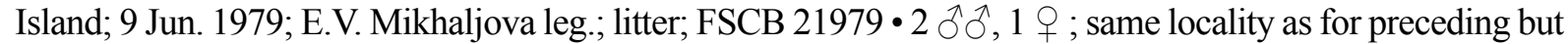
Sokolovka Cordon; 11 Jun. 1979; E.V. Mikhaljova leg.; forest, litter; FSCB $41979 \bullet 1$ ô, 3 우우 ; same locality as for preceding but Amerika Cordon; 17 Jun. 1979; E.V. Mikhaljova leg.; valley forest, litter; FSCB 71979 - 1 ठ ; same locality as for preceding but Pinus koraiensis forest; 20 Jun. 1979, E.V. Mikhaljova leg.; litter; FSCB 141979 - 1 \%; same locality as for preceding but in a glade; 4-5 Sep. 2005; S.Yu. Storozhenko, V.S. Sidorenko, S.K. Kholin and Yu.N. Sundukov leg.; pitfall traps; FSCB 162005 • 2 $\lesssim$; ; same locality as for preceding but Korpad Cordon; 2 Sep. 2005; S.Yu. Storozhenko, V.S. Sidorenko, S.K. Kholin and Yu.N. Sundukov leg.; grass meadow, pitfall traps; FSCB 142005 • 1 § ; Primorskiy krai, Chuguevskiy District, Verchneussuriiskiy Research Station; 13 Aug. 1973; G.F. Kurcheva leg.; forest; FSCB 11973 • 2 ô $\widehat{\text {; }}$; same locality as for preceding; 21-25 May 2008; S.A. Shabalin leg.; forest; FSCB $212008 \bullet 1{ }^{\lambda}$; same locality

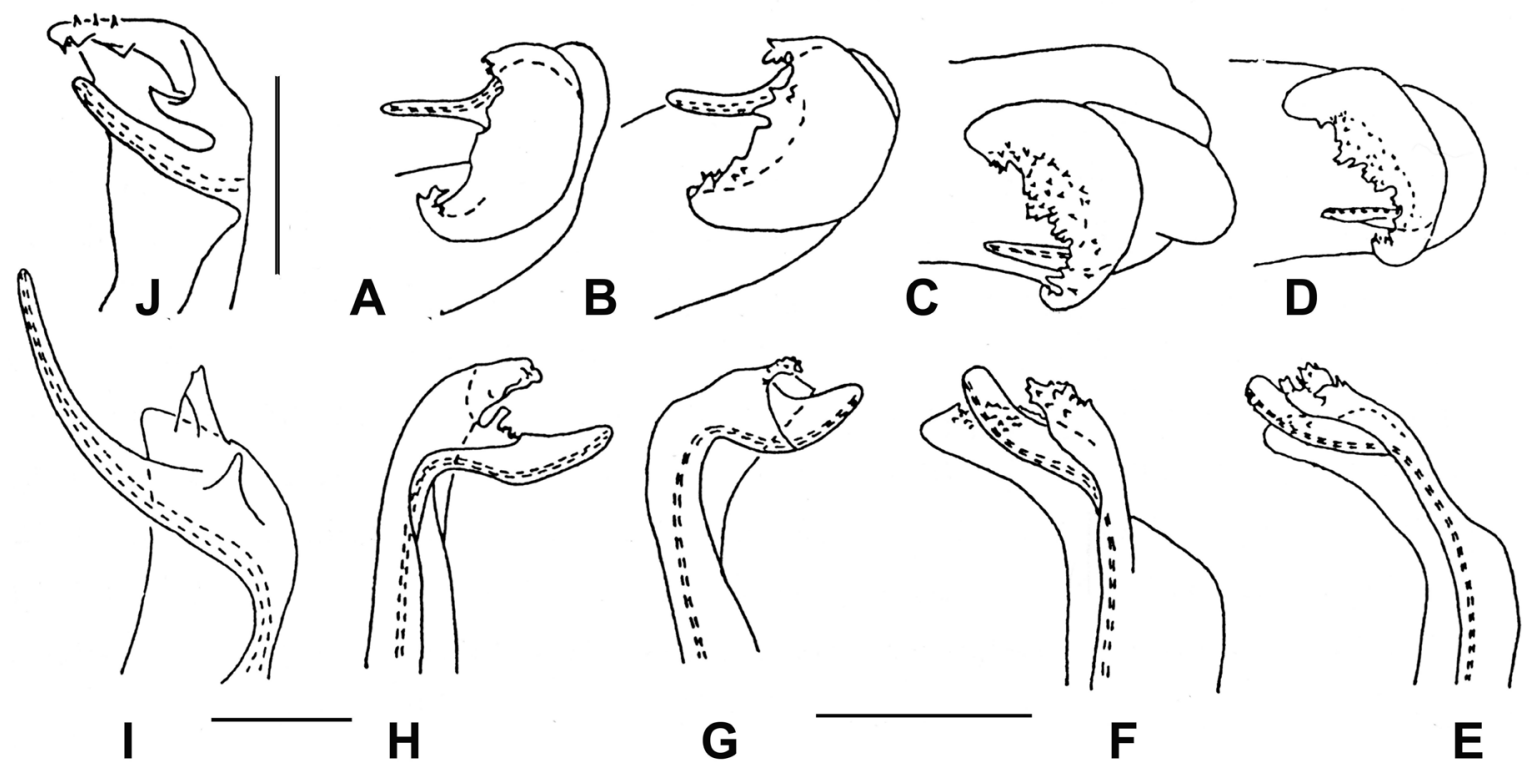

Fig. 3. Levizonus circularis Takakuwa, 1942, $\widehat{ð}$, from Russia (A-I) and North Korea (J). A-D. Variations in shape of distal part of gonopod telopodite, ventral view. E-J. Variations in shape of distal part of gonopod telopodite, lateral view. Scale bars: A-D, J $=0.25 \mathrm{~mm} ; \mathrm{E}-\mathrm{G}=0.2 \mathrm{~mm} ; \mathrm{H}-\mathrm{I}=0.1 \mathrm{~mm}$. A-H: after Mikhaljova 1981a; I: after Lokschina \& Golovatch 1977; J: after Mikhaljova et al. 2000. 
as for preceding; 27-30 Jun. 2008; S.A. Shabalin leg.; forest; FSCB $222008 \cdot 1$ त; same locality as for preceding; 21-24 Aug. 2008; S.A. Shabalin leg.; forest; FSCB 232008 • 1 §’; Primorskiy krai, Lazovskiy mountain range, Shpilka pass, near 1000 m a.s.l.; Aug. 2012; G.N. Ganin leg.; dark coniferous forest; FSCB 292012.

NORTH-EAST CHINA - Jilin Province • 1 万人; environs of Baishan town; 30 Aug. 2019; L.A. Prozorova and Guoyi Zhang leg.; FSCB 12019Ch.

Material re-examined (specimen published by Mikhaljova et al. 2000)

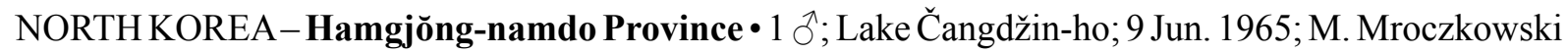
and A. Riedel leg.; FSCB 11965K.

\section{Description}

\section{Male}

SizE. Body 25-30 mm long, 3.3-3.8 mm wide.

CoLouR. Shining whitish. Tergites often patterned with lateral marbled brown spots and transverse brown stripes.

HEAD. Epicranial suture not quite reaching the level of antennal sockets. Lateral excavation of head relatively deep for accommodation of antennae. Antennae rather slender, varying from short (reaching to front edge of ring 2) to long (reaching to front edge of ring 4).

BoDy. Metaterga with bosses (Fig. 1) increasingly evident from ring 5 posteriorly, especially so in males in contrast to females and juveniles. The number and location of the bosses varies from a few (or one) only in lateral parts above peritremata to relatively numerous as transverse rows throughout each metatergite (Fig. 1B). Paraterga rounded laterally; starting from ring $12-13$, they have rounded, though never clear-cut, caudal corners.

TELSON. Caudal dorsal projection with long sparse setae, blunt apically.

LEGS. Each coxa and prefemur of postgonopodal legs distoventrally with a short conical knob becoming spineshaped in coxa toward telson. Coxa of leg 2 with a large setigerous process curved forward and terminating with gonopore.

GoNopoDs. Distal part of coxite with three strong setae laterally (two) (Fig. 2A) and mesally (one) (Fig. 2E). Telopodite laterally with longitudinal striae along almost its entire length. Distal part of telopodite with an external dentiform process (= SL) of different length. SL more (Figs 2F, 3A-I) or less (Figs 2B, 3J) strongly curved mesad and located lower or higher. Central edge of telopodite apex with outgrowths and spinules of varying shape and size (Figs $2 \mathrm{C}, 3 \mathrm{~A}-\mathrm{J}$ ).

\section{Female}

SizE. Body 25-32 mm long, 3.0-5.0 mm wide, often stouter than in male.

BoDy. Metatergal bosses either relatively well developed or traceable, same as in juvenile.

LEGS. Coxa 2 with a small, pointed, setigerous process.

Vulvae. As in Fig. 2G.

\section{Distribution}

Russia: Far East (Primorskiy krai); North Korea; North-East China. 


\section{Remarks}

This species was originally described by Takakuwa (1942) from Zyônanri (modern names: village: Sangnam-ri; county: Yeonweon-gun; province: Pyeongannam-do; North Korea). However the original description is far too fragmentary. That $L$. circularis might prove to be a senior synonym of $L$. variabilis has long been suspected (Golovatch 1979; Mikhaljova et al. 2000). So, the above male from North Korea, kept at FSCB, can be considered as near topotypic, because both localities are only a few air$\mathrm{km}$ away from one another. Unfortunately, information about the holotype of $L$. circularis could not be found; the holotype is probably lost. Maybe it was deposited in the private collection of Y. Miyosi as Takakuwa's other xystodesmid samples and was destroyed (see Tanabe 1994). Originally described from Lazovskiy (old name: Sudzukhinskiy) and Kavalerovskiy districts, Primorskiy krai, Russia (Lokschina \& Golovatch 1977), L. variabilis appears to be widespread in and confined to the south-eastern and eastern parts of the Primorskiy krai (Mikhaljova 2017). The gonopods of L. variabilis are variable (Mikhaljova 1981a; Mikhaljova et al. 2000). The telopodite apex carries outgrowths and spinules of varying shape and size (Fig. 3A-D). The SL is located somewhat lower and less strongly curved mesad in specimens from North Korea (Fig. 3J) and North-East China (Fig. 2A-B) as compared to that of Russian samples.

Supported by the geographical evidence and the morphological variability of the gonopods of L. variabilis, the following new formal synonym is proposed: Levizonus circularis Takakuwa, $1942=$ Levizonus variabilis Lokschina \& Golovatch 1977 syn. nov., the valid name being the first.

Levizonus circularis and accordingly its junior synonym L. variabilis have never been recorded from China. The species is new for the Chinese fauna.

\section{Levizonus distinctus Mikhaljova, 1990}

Figs 4, 13

Levizonus distinctus Mikhaljova, 1990: 134, fig. 1 (holotype ${ }^{\Uparrow}$, from Zimoveyniy Cordon, Sikhote-Alin State Nature Biosphere Reserve, Primorskiy krai, Russia, in ZMUM).

Levizonus distinctus - Mikhaljova 1993: 33; 1998: 53, figs 200-204, map 12; 2004: 245, figs 612-616, map 32; 2009a: 5; 2017: 295, figs 660-663, map 43. — Ganin 2011: 341. — Marek et al. 2014: 72. Levizonus distinatus (sic!) - Ganin 1997: 124.

\section{Diagnosis}

This species differs from congeners mainly by the presence of a $\mathrm{H}$ (conical process) (Fig. 4B-C) at the base of the gonopod SL (vs absence of a $\mathrm{H}$ at the base of the gonopod SL in all other congeners) and the smaller body (vs larger in all other congeners).

\section{Material examined}

RUSSIA - 1 ठ̊; Primorskiy krai, Sikhote-Alin State Nature Biosphere Reserve, Nechet Cordon; 23 Jul. 1979; M.N. Gromyko leg.; Pinus koraiensis Siebold \& Zucc. with Larix forest; FSCB 91979 - $1 \mathrm{~J}$; same locality as for preceding but Zimoveiniy Cordon; 8 Aug. 1983; M.N. Gromyko leg.; Betula valley forest, third floodplain river terrace of Serebryanka River; FSCB $11983 \bullet 1$ Oे, 1 क; same locality as for preceding but Yasnaya Cordon; 24 Jun. 1984; M.N. Gromyko leg.; Betula valley forest; FSCB 11984.

\section{Distribution}

Russia: Far East, Primorskiy krai (Sikhote-Alin State Nature Biosphere Reserve). 


\section{Remarks}

The species is known only from the original description from the Sikhote-Alin State Nature Biosphere Reserve, Primorskiy krai, Russia (Mikhaljova 1990). Gonopods and vulvae as in Fig. 4.
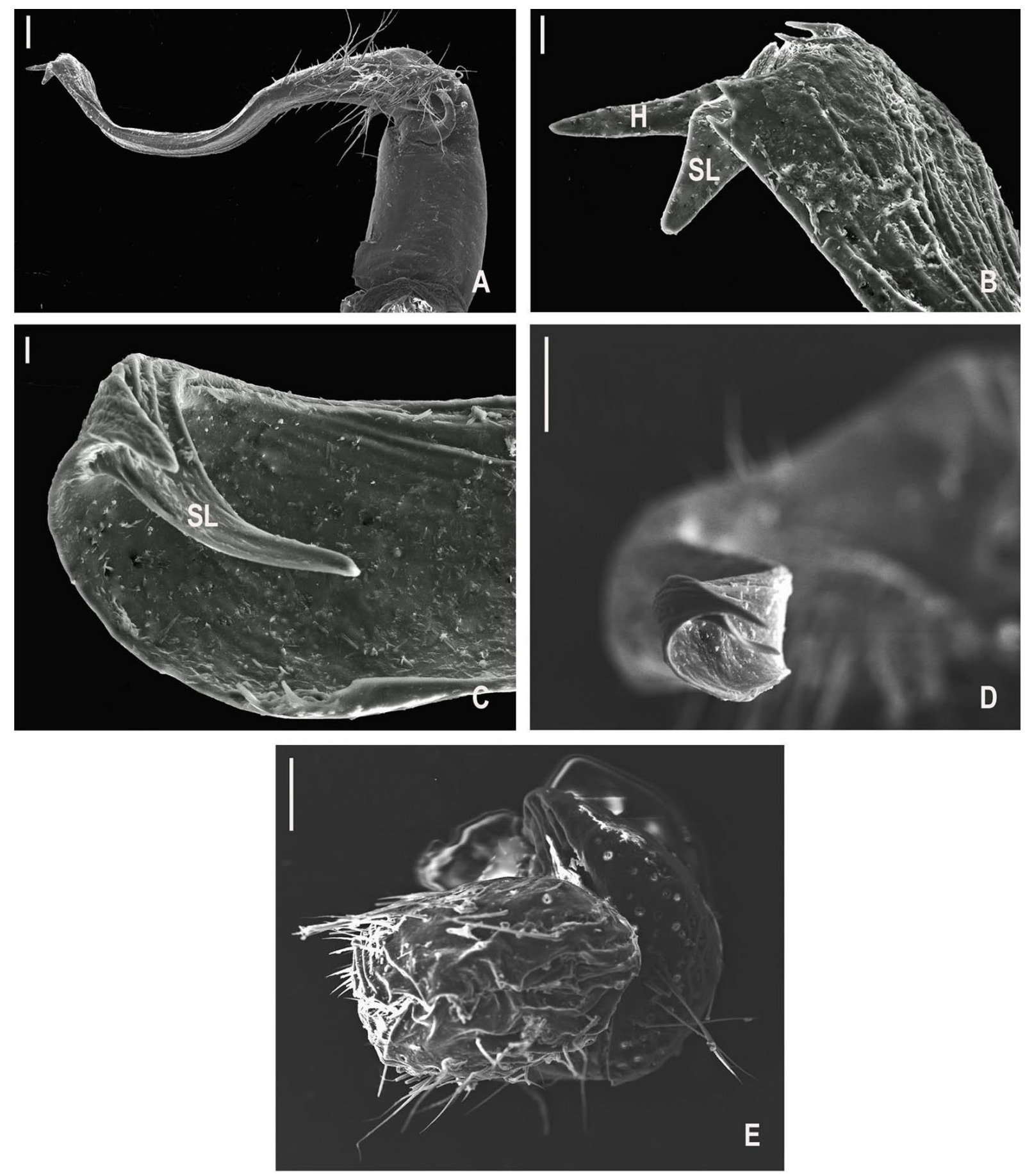

Fig. 4. Levizonus distinctus Mikhaljova, 1990, $\widehat{\partial} \partial$,, (FSCB 11983, 11984). A. Gonopod, mesal view, unnaturally curved. B. Gonopod apex, mesal view, slightly rotated around its axis. C-D. Gonopod apex, ventral view, in somewhat different angles. E. Vulva, mesal view. Scale bars: A, D-E $=100 \mu \mathrm{m}$; $\mathrm{B}=20 \mu \mathrm{m} ; \mathrm{C}=10 \mu \mathrm{m}$. 
Levizonus laqueatus Mikhaljova, 1981a: 62, fig. 1, map (fig. 5) (holotype đે, from Sokolovka Cordon, Lazovskiy Nature Reserve, Primorskiy krai, Russia, in ZMUM).

Levizonus laqueatus - Mikhaljova 1981b: 87; 1983: 81; 1990: 136; 1993: 33; 1998: 54, figs 205-209, map 12; 2004: 247, figs 617-622, map 32; 2009a: 5; 2009b: 394; 2017: 297, figs 664-669, map 43. — Mikhaljova \& Petukhova 1983: 53. — Tanabe 1994: 108. — Ganin 1997: 22; 2011: 77. — Marek et al. 2014: 72 .

\section{Diagnosis}

The species differs from its congeners mainly by the always smooth central edge of the gonopod telopodite apex (vs with one to numerous outgrowths and spinules in L. distinctus, L. thaumasius, L. circularis, L. nakhodka sp. nov., L. malewitschi) and the strong dentiform SL (Fig. 5A-E).

\section{Material examined}

RUSSIA • 1 गें Primorskiy krai, Lazovskiy State Nature Reserve, Sokolovka Cordon; 11 Jun. 1979; E.V. Mikhaljova leg.; about 2,5 km below the pass; FSCB 101979.

\section{Distribution}

Russia: Far East, Primorskiy krai (Lazovskiy State Nature Reserve).

\section{Remarks}

The species has hitherto been reported only from Lazovskiy State Nature Reserve, Primorskiy krai, Russia, its terra typica. Levizonus laqueatus is a dominant species; its abundance is $166 \mathrm{ind} . / \mathrm{m}^{2}$ (Mikhaljova 1981b). Vulva as in Fig. 5F.

Levizonus malewitschi Lokschina \& Golovatch, 1977

Figs 6, 13

Levizonus malewitschi Lokschina \& Golovatch, 1977: 73, figs 1, 2 (holotype $\widehat{~}$, from Derevyankina Ravine, Kavalerovskiy District, Primorskiy krai, Russia, in ZMUM).

Levizonus malewitschi - Lokšina \& Golovatch 1979: 385. — Kurcheva \& Mikhaljova 1980: 120. —Mikhaljova 1981a: 66, map (fig. 5); 1983: 81; 1990: 136; 1993: 33; 1998: 52, figs 196-199, map 12; 2004: 243, figs 608-611, map 32; 2009a: 5; 2017: 294, figs 656-659, map 43. — Mikhaljova \& Petukhova 1983: 53. — Gromyko 1990: 63. — Ganin 1997: 124; 2011: 341. — Marek et al. $2014: 72$.

Levizonus malevitschi [sic!] - Tanabe 1994: 108, fig. 4; 2002: 2178.

\section{Diagnosis}

The species differs from its congeners mainly by the configuration of the gonopod telopodite apex, like two plates placed perpendicular to each other, the central one with a seminal groove, the second one being serrate at its outer margin (Fig. 6A-B) (vs without two plates in all congeners).

Material re-examined (specimens published by Mikhaljova 1993)

RUSSIA • 1 क; Primorskiy krai, Sikhote-Alin State Nature Biosphere Reserve, Blagodatnoe; 22 Sep. 1982; M.N. Gromyko leg.; Quercus mongolica Fisch. ex Ledeb. forest; FSCB $11982 \bullet 1$ ○; same locality as for preceding; 26-27 Jun. 1986; M.N. Gromyko leg.; FSCB 11986. 

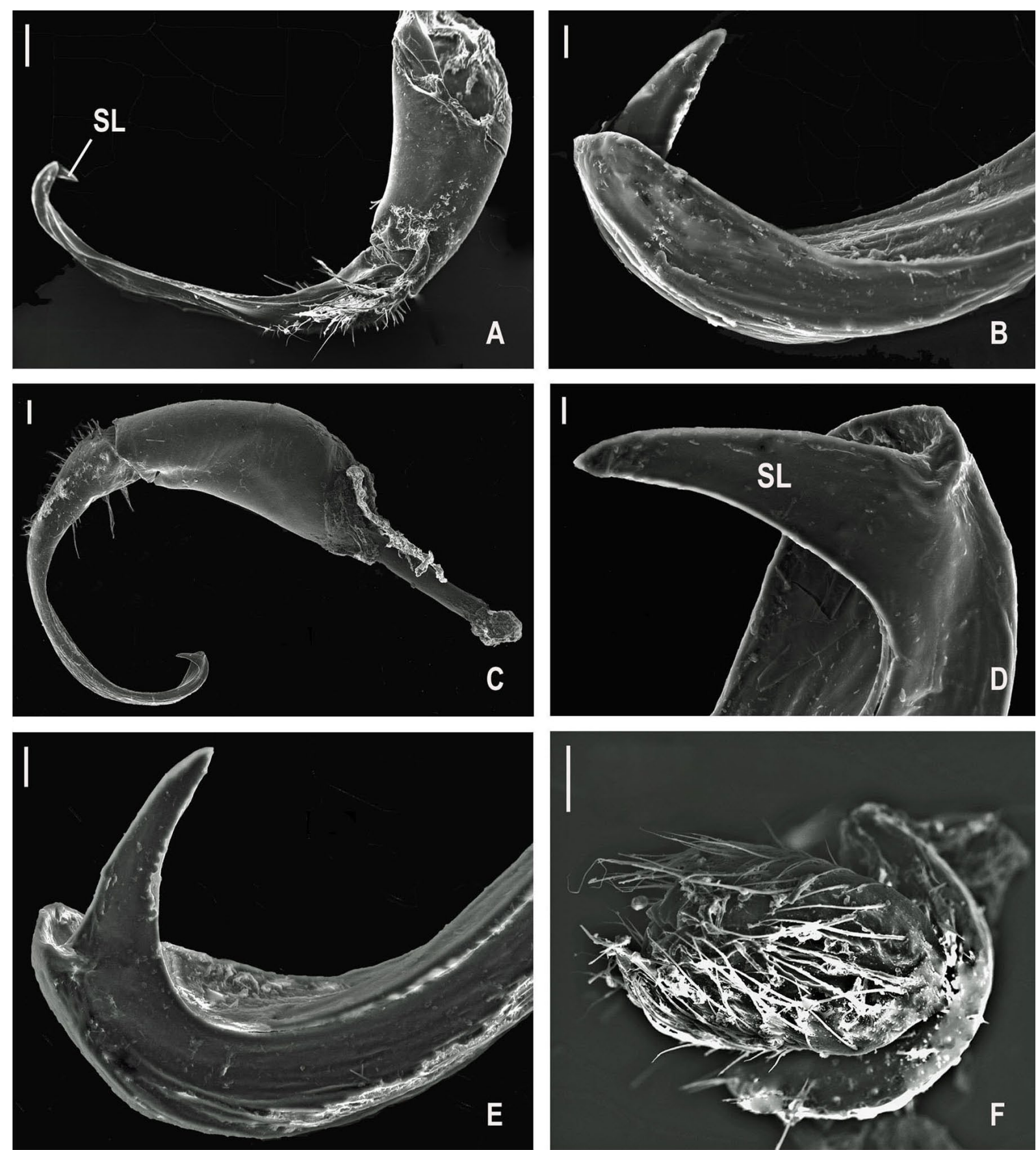

Fig. 5. Levizonus laqueatus Mikhaljova, 1981, $0^{2}$, + (FSCB 101979). A. Gonopod, mesal view. B. Gonopod apex, mesal view. C. Gonopod, lateral view. D. Gonopod apex, lateral view. E. Gonopod apex, ventral view, slightly turned mesally. F. Vulva, ventromesal view. Scale bars: A $=200 \mu \mathrm{m}$; C, $\mathrm{F}=100 \mu \mathrm{m} ; \mathrm{B}, \mathrm{E}=20 \mu \mathrm{m} ; \mathrm{D}=10 \mu \mathrm{m}$. 


\section{Distribution}

Russia: Far East, Primorskiy krai.

\section{Remarks}

Originally described from Kavalerovskiy District, Primorskiy krai, Russia (Lokschina \& Golovatch 1977), this species appears to be distributed in eastern and central parts of the Primorskiy krai (Mikhaljova 2017). The abundance ranges from 3.5 ind. $/ \mathrm{m}^{2}$ in mountainous forest to $62 \mathrm{ind} . / \mathrm{m}^{2}$ in valley forests (Kurcheva \& Mikhaljova 1980). Vulva as in Fig. 6C.

\section{Levizonus montanus (Takakuwa, 1941)}

Fig. 13

Ezaria montana Takakuwa, 1941: 9, fig. 10 (syntypes destroyed; type locality: Hokkaido, Japan).

Japonaria (Japonaria) hamuligera Kraus, 1960: 2, figs 1-3 (syntypes in Zoologische Sammlung des Bayerischen Staates, Munich, Germany; type locality: Hokkaido, Japan; synonymized by Tanabe 1994).

Ezaria montana - Takakuwa 1954: 87, fig. 97. - Miyosi 1959: 83, fig. 101. - Jeekel 1971: 264.

— Tanabe 1994: 103. Synonymized by Hoffman (1980).
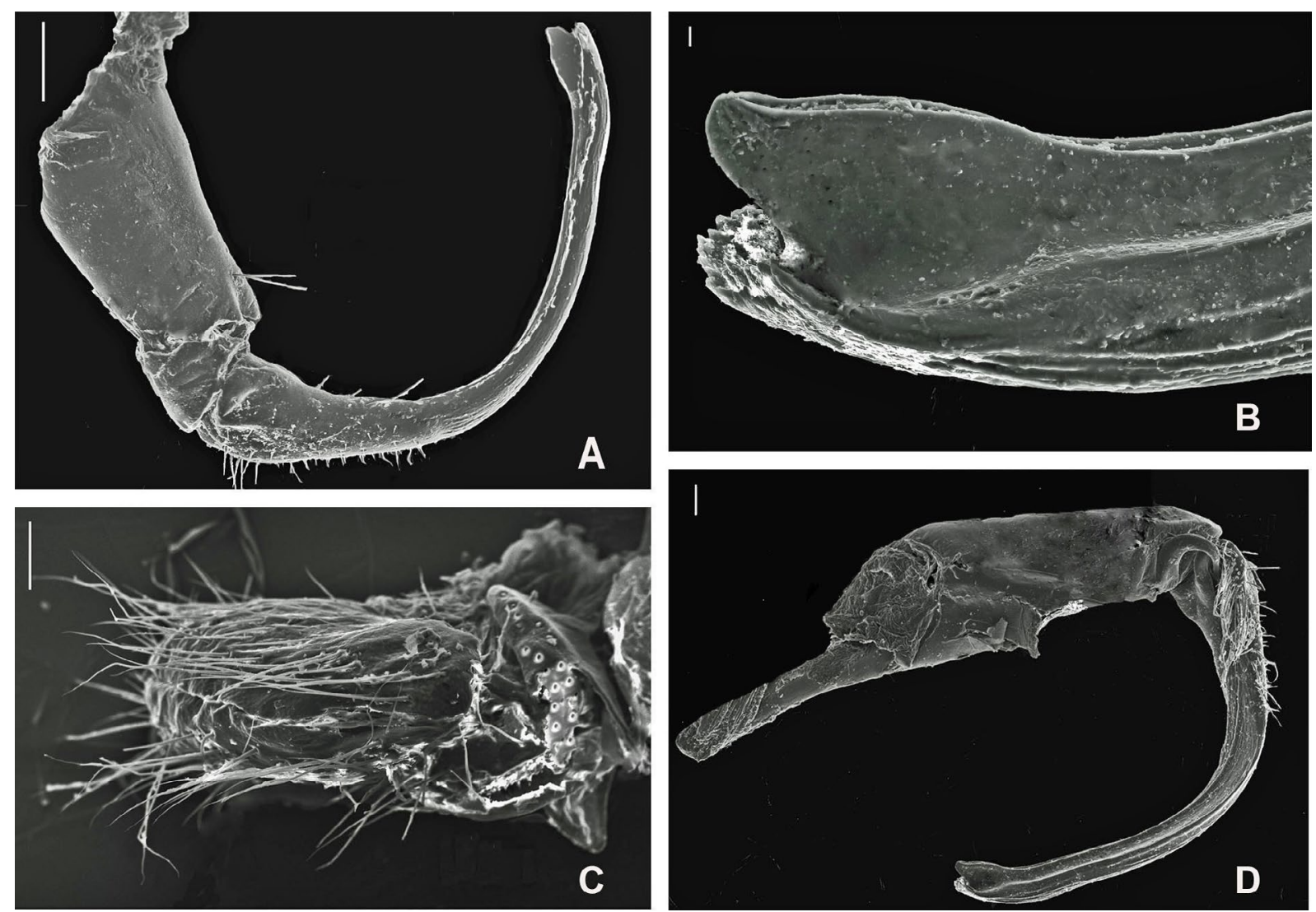

Fig. 6. Levizonus malewitschi Lokschina \& Golovatch, 1977, ð̊ (FSCB 11986) and $q$ (FSCB 11982). A. Gonopod, lateral view. B. Gonopod apex, mesal view. C. Vulva, mesal view. D. Gonopod, mesal view. Scale bars: $\mathrm{A}=200 \mu \mathrm{m} ; \mathrm{C}-\mathrm{D}=100 \mu \mathrm{m} ; \mathrm{B}=10 \mu \mathrm{m}$. 
Levizonus montanus - Tanabe 1992: 87; 1994: 103, figs 1-3; 2002: 2178. — Marek et al. 2014: 72. - Tanabe \& Sota 2014: figs S2-S4, tables S1-S3.

Non Profontaria takakuwai-Murakami 1972: 59, fig. 2.

Diagnosis (after Tanabe 1994)

The species differs from congeners mainly by the straight gonopod telopodite apex (vs hooked in other congeners) with elongated, acute lateral angle (= SL) (vs different in other congeners) as well as the smooth central margin of the telopodite apex (vs with outgrowths and spinules in L. circularis, L. thaumasius, L. nakhodka sp. nov., L. distinctus, L. malewitschi).

\title{
Distribution
}

Japan: central part of Hokkaido.

\section{Remarks}

This species was originally described by Takakuwa (1941) from Hokkaido Island with several collection points (Sapporo, Rumoi, Mt. Daisetu). Unfortunately he did not denote the precise type locality. Nevertheless Levizonus montanus appears to be spread in central part of Hokkaido (see Tanabe 1994).

\author{
Levizonus nakhodka sp. nov. \\ urn:lsid:zoobank.org:act:E92C7403-59C4-4AAC-A645-81075397DCE6
}

Figs $7-9,13$

\section{Diagnosis}

The species differs from congeners mainly by the configuration of the gonopod telopodite with subapical large K laterally (Fig. 8A) (vs without the outgrowth in other congeners excluding L. thaumasius and L. circularis; small not knee-shaped in both), with central apical arcuate P carrying numerous, small outgrowths (Fig. 8B) (vs without protrusion and outgrowths in L. montanus, L. takakuwai, L. malewitschi, L. laqueatus, L. distinctus).

The species seems to be particularly similar to L. thaumasius but differs in a telopodite apex strongly curved caudad and as a result a large well-developed lateral subapical K (Fig. 8C) (vs low, not kneeshaped outgrowth (K1) in L. thaumasius, Fig. 10D), as well as the narrower apex of telopodite, permanent presence of a central P on telopodite apex and by a stick-like SL (Fig. 8B-D).

\section{Etymology}

The specific epithet refers to the type locality, a noun in apposition.

\section{Material examined}

\section{Holotype}

RUSSIA - गे; Primorskiy krai, environs of Nakhodka City; 1-3 Aug. 2015; S.A. Shabalin leg.; Quercus forest with fern; FSCB 12020.

\section{Paratypes}

RUSSIA $\bullet 2 \widehat{\partial} \widehat{\partial}, 1$ fragment; same locality as for holotype; 30 Jul.-1 Aug. 2015; S.A. Shabalin leg.; FSCB 22020 - 2 ठิ $\sigma^{\text {; }}$ same locality as for holotype but Quercus forest with Lespedeza; 30 Jul.-

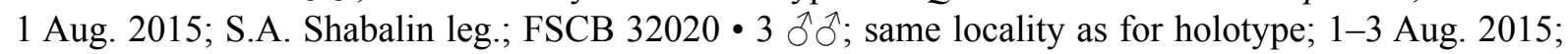
S.A. Shabalin leg.; FSCB 42020 - 2 §ô; same locality as for holotype but Quercus forest with Lespedeza; 1-3 Aug. 2015; S.A. Shabalin leg.; FSCB 52020 • 1 ô, 1 \&; same locality as for holotype but 

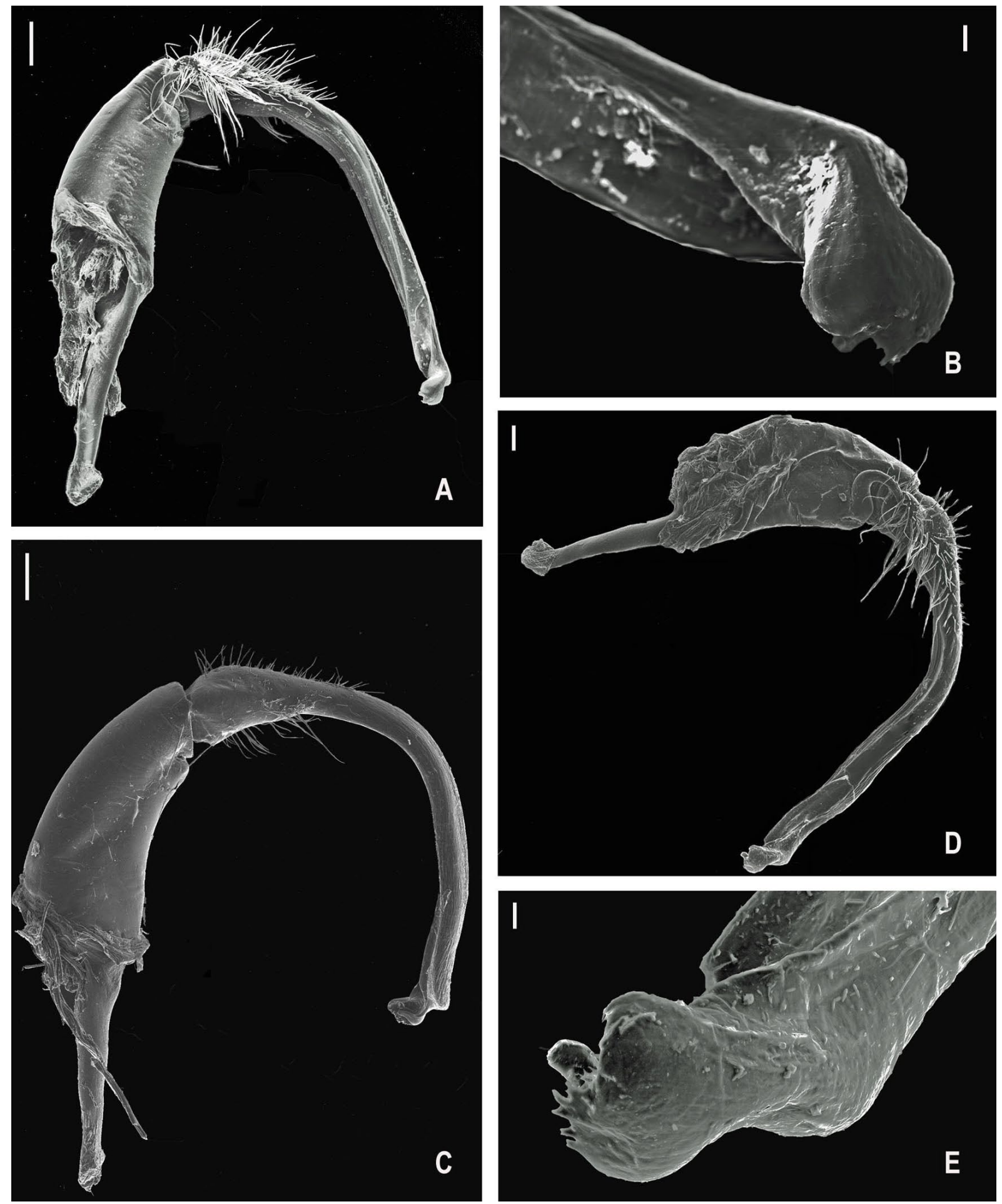

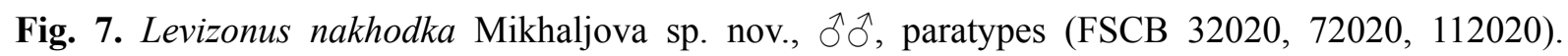
A, D. Gonopod, mesal view. B, E. Gonopod apex, mesoventral view. C. Gonopod, lateral view. Scale bars: $\mathrm{A}, \mathrm{C}=200 \mu \mathrm{m} ; \mathrm{D}=100 \mu \mathrm{m} ; \mathrm{B}, \mathrm{E}=20 \mu \mathrm{m}$. 
42 $50^{\prime} 27.9^{\prime \prime}$ N, 13247'30.5" E; 19-22 Aug. 2015, S.A. Shabalin and E. Poletkov leg.; FSCB 142020 • $1 \mathrm{O}^{\wedge}, 1$ \%; same locality as for holotype but $42^{\circ} 53^{\prime} 13.5^{\prime \prime} \mathrm{N}, 132^{\circ} 43^{\prime} 04.8^{\prime \prime} \mathrm{E}$; Sep. 2015; Maslovsky leg.; ZMUM - 2 우; same locality as for holotype but 42 $53^{\prime} 13.5^{\prime \prime} \mathrm{N}, 132^{\circ} 43^{\prime} 04.8^{\prime \prime}$ E; Sep. 2015; Maslovsky leg.; FSCB 62020 • 1 万े; same locality as for holotype; 7 Sep. 2015; Maslovsky leg.; FSCB 72020 - 1 क ; same locality as for holotype but 42 $53^{\prime} 22.0^{\prime \prime} \mathrm{N}, 132^{\circ} 49^{\prime} 37.2^{\prime \prime} \mathrm{E}$; 9-12 Sep. 2015, S.A. Shabalin and S.Yu. Storozhenko leg.; FSCB 82020 • 1 त; same locality as for holotype but $42^{\circ} 53^{\prime} 05.4^{\prime \prime} \mathrm{N}, 132^{\circ} 48^{\prime} 47.5^{\prime \prime}$ E; 9-12 Sep. 2015, S.A. Shabalin and S.Yu. Storozhenko leg.; Ulmus,

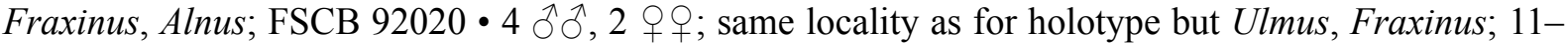
14 Sep. 2015; S.A. Shabalin and S.Yu. Storozhenko leg.; FSCB 102020 $2 \hat{\jmath} \widehat{\partial}, 1$ q; same locality as for holotype but 42 ${ }^{\circ} 3^{\prime} 11.6^{\prime \prime}$ N, 132 $48^{\prime} 03.6^{\prime \prime}$ E; 11-14 Sep. 2015; S.A. Shabalin and S.Yu. Storozhenko leg.; Quercus forest with Lespedeza; FSCB $112020 \cdot 2 \widehat{\partial^{\lambda}, 1}+1$, 1 fragment; same locality as for holotype but 42 ${ }^{\circ} 3^{\prime} 22.0^{\prime \prime} \mathrm{N}, 132^{\circ} 49^{\prime} 32.7^{\prime \prime}$ E; 12-15 Sep. 2015; S.A. Shabalin and S.Yu. Storozhenko leg.; FSCB 122020 • 1 'ं; same locality as for holotype but $42^{\circ} 53^{\prime} 07.6^{\prime \prime} \mathrm{N}, 132^{\circ} 48^{\prime} 46.3^{\prime \prime} \mathrm{E}$; $12-15$ Sep. 2015; S.A. Shabalin and S.Yu. Storozhenko leg.; Quercus dentata forest; FSCB 132020.

\section{Description}

Male

SizE. Body $25-27 \mathrm{~mm}$ long, 4.0-4.3 mm wide.

Colour. Shining whitish in alcohol, tergites often beige.

HEAD. Epicranial suture not quite reaching the level of antennal sockets. Lateral excavation of head relatively deep for accommodation of antennae. Antennae rather slender, in situ reaching to the front edge of ring 4.

Body. Metaterga without bosses. Paraterga rounded laterally. Starting from ring 12-13, they have rounded, though never clear-cut, caudal corners.

TeLson. Caudal dorsal projection with relatively long sparse setae, blunt apically, often apex with tiny excavation.

Legs. Each coxa of hind legs distoventrally with a small conical outgrowth. Coxa of leg 2 with a large setigerous process curved forward and terminating a vas deferens.

Gonopods. Distal part of coxite with three strong setae mesally (one) and laterally (two) (Fig. 9A). Telopodite laterally with longitudinal striae along almost its entire length (Fig. 8A). Telopodite apex relatively sharply curved mesad, as result distal part of the telopodite laterally carrying a large subapical $\mathrm{K}$ (Figs 8A, 8C, 9B). Apical part of telopodite with an external stick-like process (= SL) curved mesad as well as always with central $\mathrm{P}$ carrying numerous, small outgrowths (Figs $8 \mathrm{~B}-\mathrm{C}, 9 \mathrm{~B}$ ). Inner edge of telopodite apex with several small outgrowths.

\section{Female}

SizE. Body 25-27 mm long, 4.0-4.7 mm wide. Body often stouter than in male.

LEG 2. Coxa 2 with a small, pointed, setigerous process.

Vulvae. As in Fig. 8E.

\section{Distribution}

Russia, Far East, Primorskiy krai. 

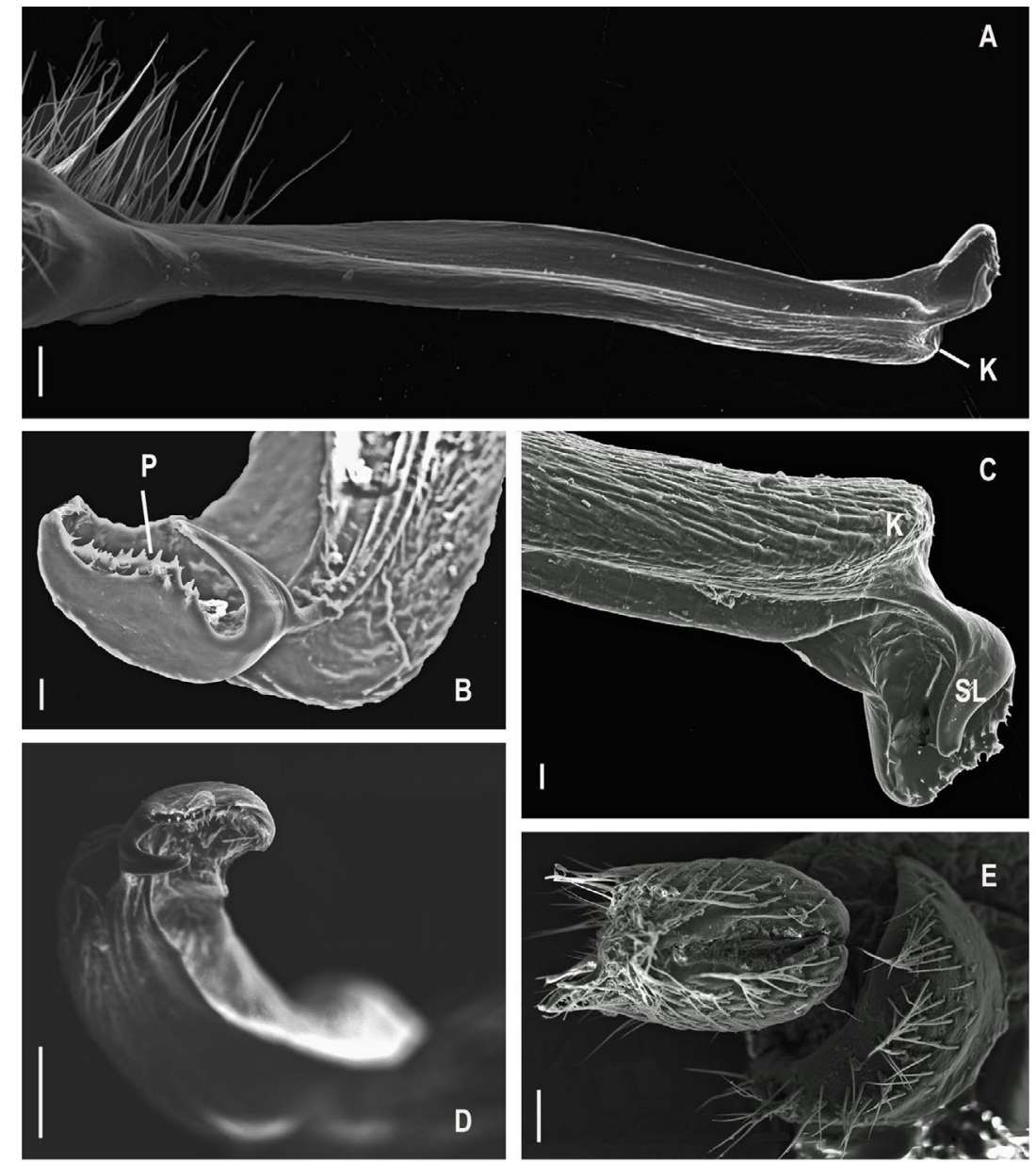

Fig. 8. Levizonus nakhodka Mikhaljova sp. nov., §ิ $\widehat{\partial}$, paratypes (FSCB 22020, FSCB 112020) and + , paratype (FSCB 122020). A. Gonopod telopodite, lateral view. B, D. Gonopod apex from slightly different angles, ventral view. C. Distal part of gonopod, lateral view. E. Vulva, mesal view. Scale bars: A, D-E $=200 \mu \mathrm{m} ; \mathrm{B}, \mathrm{C}=20 \mu \mathrm{m}$.
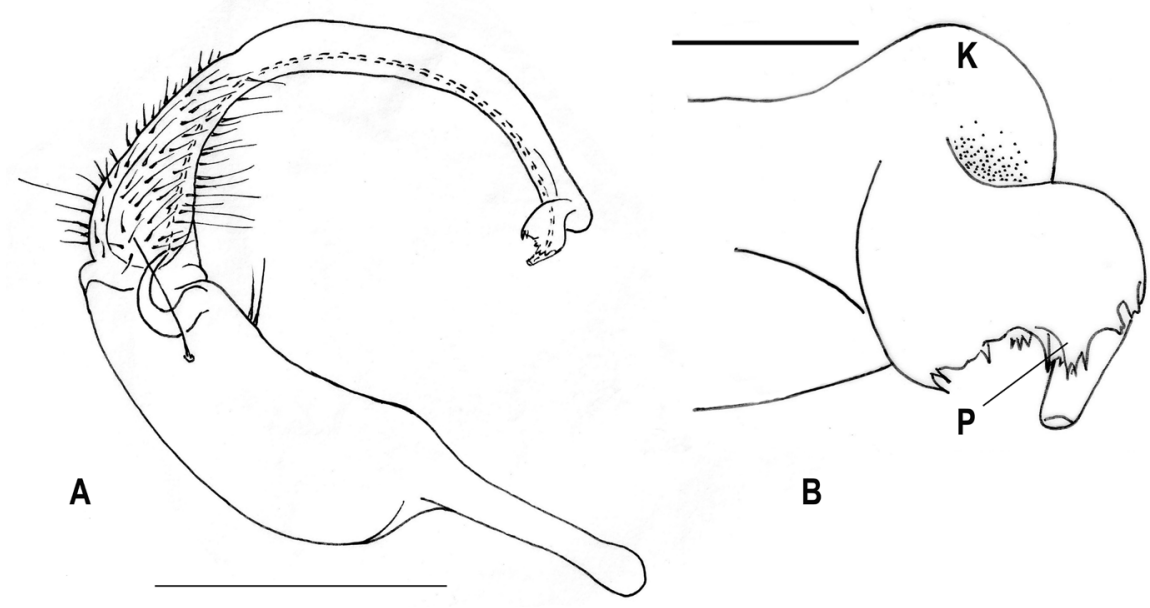

B

Fig. 9. Levizonus nakhodka Mikhaljova sp. nov., ${ }^{\wedge}$, paratype (FSCB 72020). A. Gonopod, mesal view. B. Gonopod apex, mesal view. Scale bars: $\mathrm{A}=1.0 \mathrm{~mm} ; \mathrm{B}=0.1 \mathrm{~mm}$. 


\section{Levizonus takakuwai (Verhoeff, 1941)}

Fig. 13

Profontaria takakuwai Verhoeff, 1941: 412, figs 2-4 (types may be deposited in Zoologisches Museum Berlin, Germany, after Tanabe 1994; type locality: Sapporo, Hokkaido, Japan; synonymized by Tanabe 1994).

Ezodesmus lunatus Takakuwa, 1942: 43, fig. 7 (types destroyed; type locality: Sapporo, Hokkaido, Japan; synonymized by Miyosi 1959).

Profontaria takakuwai - Hoffman 1956: 99. — Miyosi 1959: 82, figs 99, 99'. — Tanabe 1994: 109.

Ezodesmus lunatus - Chamberlin \& Wang 1953: 7. — Takakuwa 1954: 86, figs 95-96. — Tanabe 1994: 109.

Levizonus takakuwai - Tanabe 1994: 109, figs 3, 5; 2002: 2178. — Tanabe \& Sota 2014: 444, fig. S2, tables S1-S3. — Marek et al. 2014: 72.

Diagnosis (after Tanabe 1994)

The species differs from all congeners mainly by the shorter gonopod telopodite carrying a longitudinal blade and by a trifurcate apex of telopodite.

\section{Distribution}

Japan: western part of Hokkaido.

\section{Remarks}

This species was originally described from Hokkaido Island as Profontaria takakuwai (see Verhoeff 1941). The genus Profontaria was later shown to be a senior synonym of originally a Hokkaido genus Ezodesmus (Hoffman 1956). Miyosi (1959) synonymized the type species Ezodesmus lunatus with Profontaria takakuwai. Finally Tanabe (1994) proposed Profontaria to be a junior synonym of Levizonus, with the new combination Levizonus takakuwai. This species appears to be distributed in the western part of Hokkaido (see Tanabe 1994).

\section{Levizonus thaumasius Attems, 1898} Figs 10-13

Sulciferus (Levizonus) thaumasius Attems, 1898: 352, fig. 112 (holotype not designated; location of types is unknown; type locality: Vladivostok, Russia).

Levizonus orientalis Lokschina \& Golovatch, 1977: 77, figs 4-5 (holotype $\widehat{\partial}$, from Varfolomeevka, Yakovlevskiy District, Primorskiy krai, Russia, in ZMUM; synonymized by Golovatch 1979).

Sulciferus (Levizonus) thaumasius - Attems 1904: 48.

Levizonus thaumasius - Attems 1931: 69, fig. 105; 1938: 173, figs 190-191. — Verhoeff 1936: 152. — Takakuwa 1942: 43. — Jeekel 1971: 270. — Golovatch 1979: 17, figs — Lokšina \& Golovatch 1979: 385. — Mikhaljova 1981a: 64, fig. 3, map (fig. 5); 1983: 81; 1984: 14; 1988: 70; 1990: 136; 1993: 33; 1997: 143; 1998: 55, figs 210-217, map 12; 2002: 150; 2004: 249, figs 623-637, map 32; 2009a: 5; 2009b: 606; 2016: 22; 2017: 299, figs 670-684, map 43. — Mikhaljova \& Petukhova 1983: 53. - Mikhaljova \& Bakurov 1989: 40. — Ganin 1997: 121; 2009: 153; 2011: 336. — Tanabe 1994: 108; 2002: 2178. — Mikhaljova \& Korsós 2003: 234. — Marek et al. 2014: 73.

Levizonus orientalis - Mikhaljova 1978: 157. 

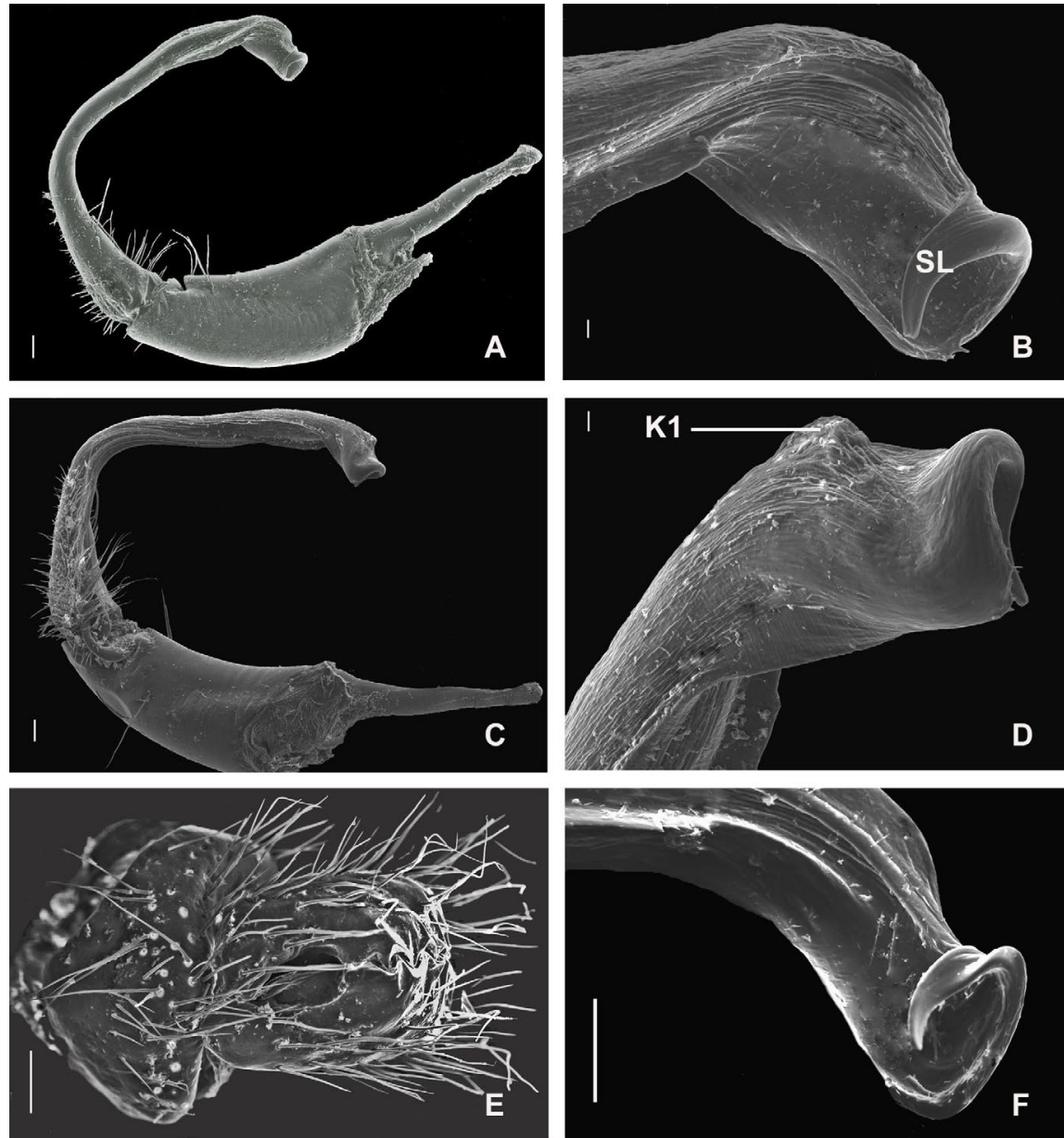

Fig. 10. Levizonus thaumasius Attems, 1898, ô $\widehat{\partial}$, $q$ (FSCB 12007, 12016). A. Gonopod, lateral view. B. Gonopod apex, lateral view. C. Gonopod, mesal view. D. Gonopod apex, mesal view. E. Vulva, mesal view. F. Gonopod apex, lateral view. Scale bars: A $=200 \mu \mathrm{m}$; C, E-F $=100 \mu \mathrm{m} ; \mathrm{B}, \mathrm{D}=20 \mu \mathrm{m}$.
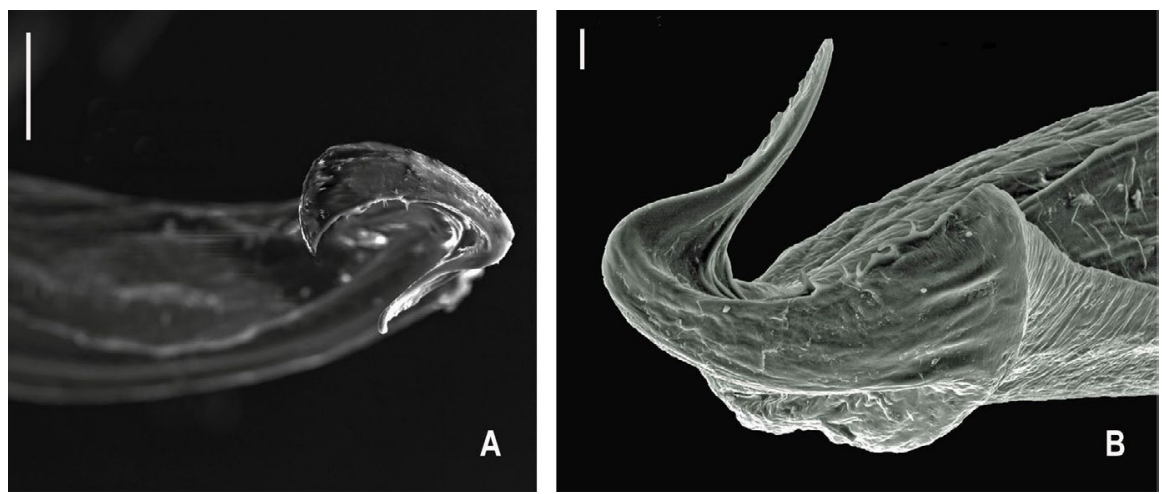

Fig. 11. Levizonus thaumasius Attems, 1898, ठิઠ (FSCB 12016). A-B. Gonopod apex, ventral view. Scale bars: $\mathrm{A}=100 \mu \mathrm{m} ; \mathrm{B}=20 \mu \mathrm{m}$. 


\section{Diagnosis}

The species differs from congeners mainly by the configuration of the central edge of the gonopod telopodite apex, which is smooth (rarely) or with one to numerous small outgrowths (Figs 10B, 11B several outgrowths) (vs without outgrowths in L. laqueatus, L. montanus, L. takakuwai), the gonopod telopodite with a low subapical not knee-shaped outgrowth (K1) (Fig. 10D) (vs without the outgrowth in other congeners excluding $L$. nakhodka sp. nov. and L. circularis; with $\mathrm{K}$ in L. nakhodka sp. nov.; not knee-shaped in L. circularis) and with a curved SL (Fig. 10B) positioned laterally (vs straight in other congeners excluding L. circularis; positioned mesad in L. circularis).

\section{Material examined}

RUSSIA • 1 O ; Primorskiy krai, Shkotovskiy District, near Anisimovka, Litovka Mountain; 22 Sep. 2007; A. Rodionov leg.; mixed forest; FSCB 12007 - 2 ते $\partial^{\lambda} 1$ क ; Primorskiy krai, Ussuriyskiy District, environs of village Utesnoe; 7 Oct. 2016; E.V. Mikhaljova and A.I. Konyukhov leg.; broadleaved forest, litter; FSCB 12016.

\section{Distribution}

Russia: Far East, Primorskiy krai.

\section{Remarks}

Originally described from the environs of Vladivostok, Primorskiy krai, Russia (Attems, 1898), this species is common and abundant in the western and central parts of the Primorskiy krai (Mikhaljova 2017). The dorsum is often distinctively patterned (Fig. 12A-B). Its abundance ranges from 24 to $86.5 \mathrm{ind} . / \mathrm{m}^{2}$ in montane forests (the maximum abundance recorded is $172.5 \mathrm{ind} . / \mathrm{m}^{2}$ ), but this species is not numerous (4 ind. $/ \mathrm{m}^{2}$ ) in floodplain forests (Mikhaljova 1988). Vulva as in Fig. 10E.

\section{Key to the species of Levizonus}

1. Metatergal surface with low bosses either everywhere (Fig. 1A-B) or only laterally. Gonopods as in Fig. 2A-D

L. circularis Takakuwa, 1942

- Metatergal surface smooth, without any bosses. Gonopods different ...

2. Apex of gonopod telopodite like two plates placed perpendicular to each other (Fig. 6A-B) ..................................................... malewitschi Lokschina \& Golovatch, 1977

- Apex of gonopod telopodite not like two plates placed perpendicular to each other .........3

3. SL with a large long H basally (Fig. 4B-D)..................... distinctus Mikhaljova, 1990

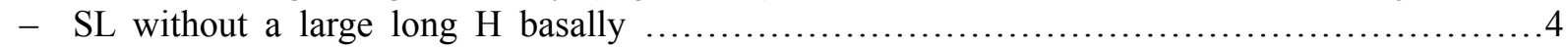

4. Telopodite apex trifurcate ..................................... takakuwai (Verhoeff, 1941)

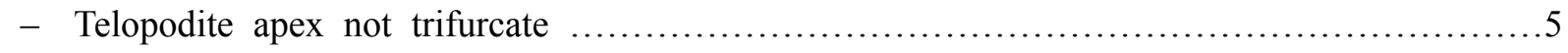

5. SL massive, dentiform. (Fig. 5B-D) ............................ laqueatus Mikhaljova, 1981

- SL not massive, not dentiform ........................................................

6. Apical edge of telopodite without numerous small outgrowths ......L. montanus (Takakuwa, 1941)

- Apical edge of telopodite with one to numerous small outgrowths, seldom smooth ................7

7. Telopodite subapically with lateral large knee-shaped protrusion (K) (Fig. 8C). Telopodite apex narrower (Fig. 8D) ..................................... nakhodka Mikhaljova sp. nov.

- Telopodite subapically with lateral small rounded protrusion (K1) (Fig. 10A-D). Telopodite apex broader (Fig. 11A) ............................................ thaumasius Attems, 1898 
MIKHALJOVA E.V., Review of the millipede genus Levizonus (Diplopoda, Polydesmida)
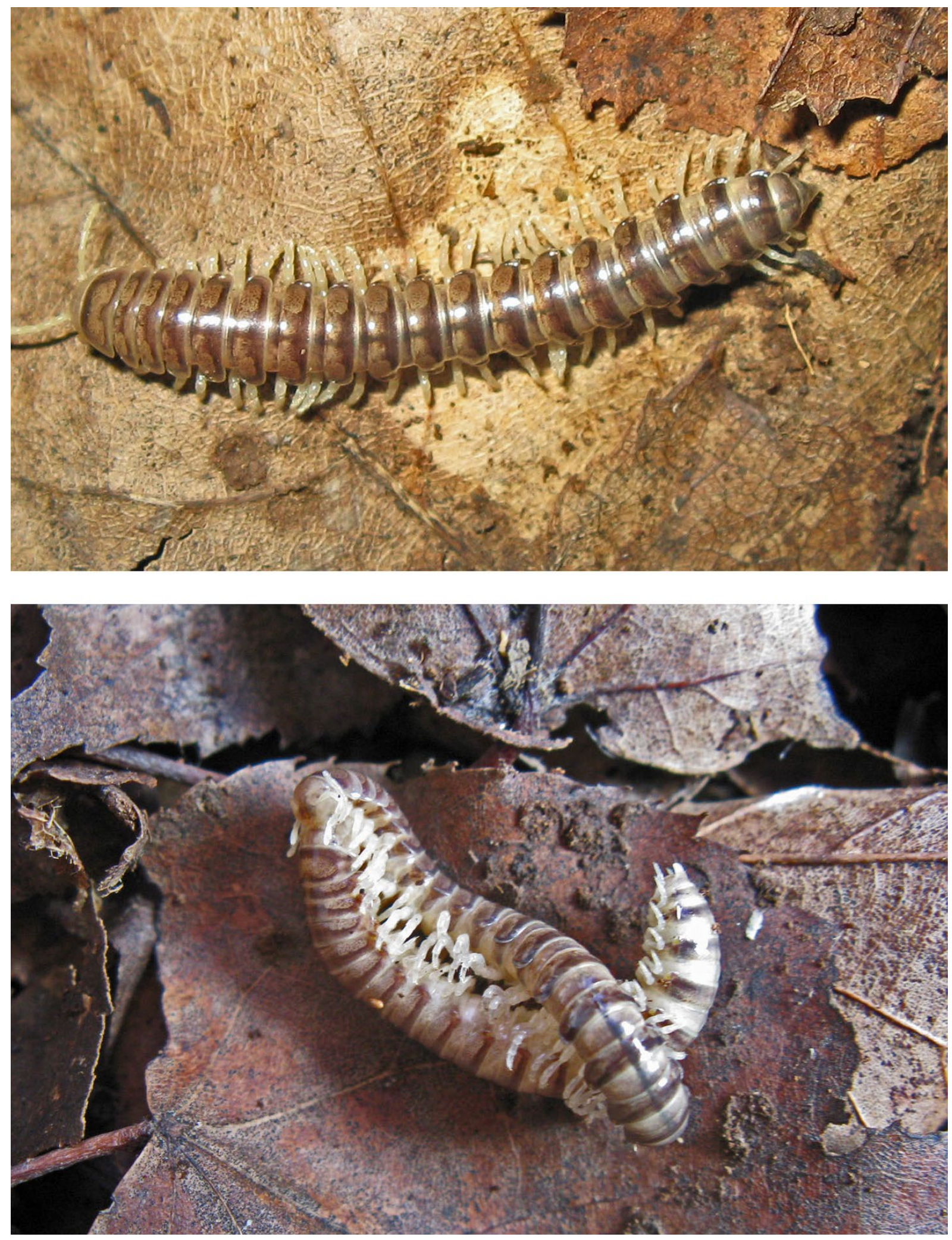

Fig. 12. Levizonus thaumasius Attems, 1898, $\delta$ and $\rho$. A. Habitus, dorsal view. B. Copulation. Photographed not to scale. Photo by the author. 


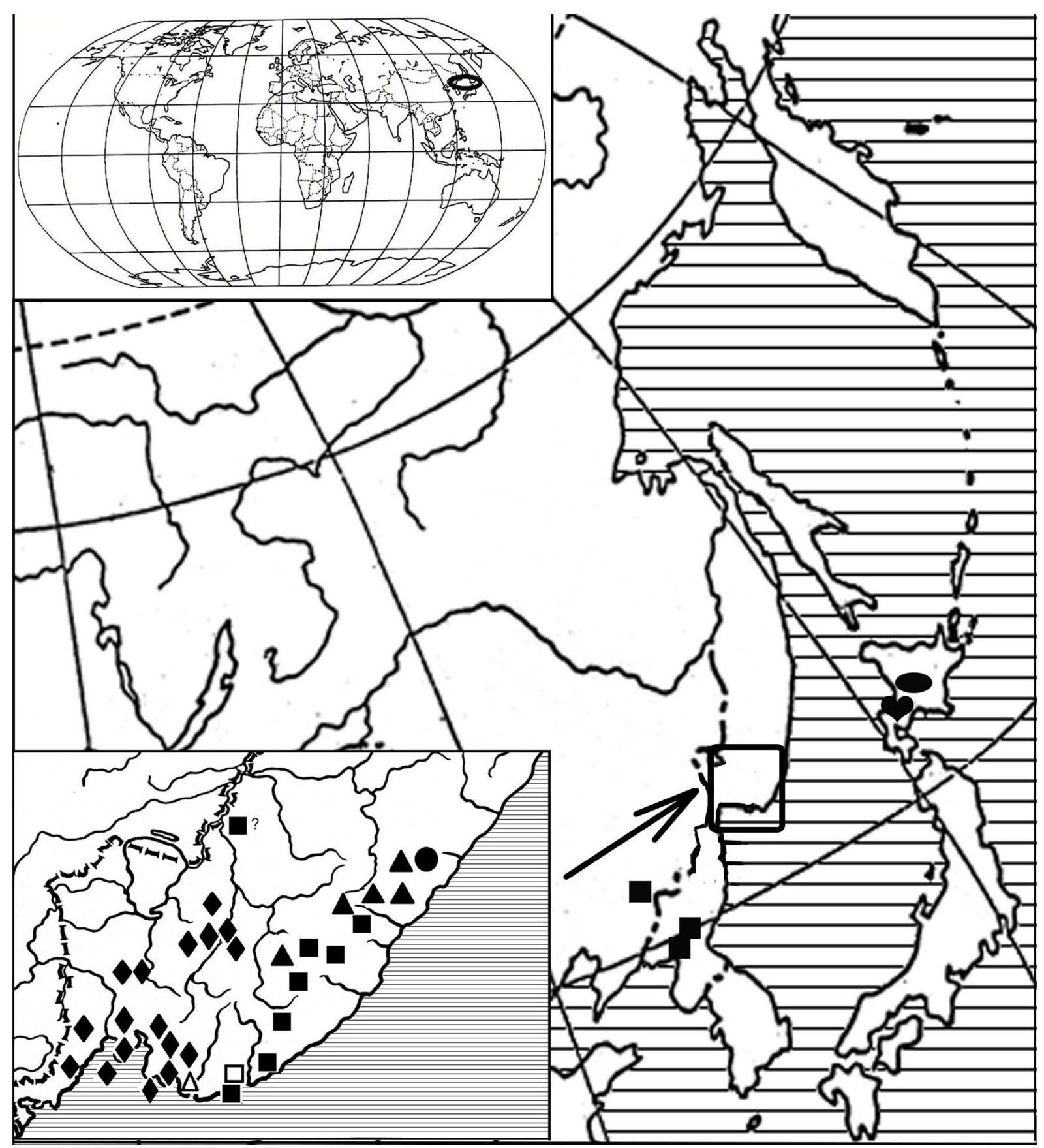

Fig. 13. Distribution of species of the genus Levizonus Attems, 1898. Filled square: L. circularis Takakuwa, 1942. Filled circle: L. distinctus Mikhaljova, 1990. Open square: L. laqueatus Mikhaljova, 1981. Open triangle: L. nakhodka Mikhaljova sp. nov. Filled triangle: L. malewitschi Lokschina \& Golovatch, 1977. Filled diamond: L. thaumasius Attems, 1898. Heart: L. takakuwai (Verhoeff, 1941). Oval: L. montanus (Takakuwa, 1941). 


\section{Discussion}

At the moment, the genus Levizonus is represented by eight species (including a new species described here) in the Far East of Russia (Primorskiy krai), Japan (Hokkaido Island), North Korea and North-East China (Fig. 13). Five of the species seem to be endemic to Russia, and two are endemic to Japan. Only L. circularis is known from Russia, North Korea and North-East China. Only three species appear to be relatively widespread in the Far East of Russia. Levizonus thaumasius seems to be confined to the central and central-western parts of the Primorskiy krai. Levizonus circularis is distributed mainly in the eastern territory, whereas L. malewitschi occurs chiefly in the north-eastern part of this region. The remaining Russian congeners tend to be more local in distribution: L. distinctus is recorded only in the Sikhote-Alin State Nature Biosphere Reserve, L. laqueatus in the Lazovskiy State Nature Reserve and L. nakhodka sp. nov. in the environs of Nakhodka. Japanese species of Levizonus are found in the central (L. montanus) and western (L. takakuwai) parts of Hokkaido Island (see Tanabe 1994). Members of the genus live mainly in various forests at low and middle altitudes. Russian species of Levizonus are characterized by an extended period of reproduction, with the dominance of soil-dwelling juveniles over adults that prefer to live in litter (Mikhaljova 1983). As a rule, they are dominant in millipede communities in forests with mature soil.

\section{Acknowledgements}

I am most grateful to all the collectors who entrusted their material to me. Dr T. Tanabe (Kumamoto, Japan) and Dr P. Marek (Virginia, USA) kindly sent the some of the reference papers. I also thank Dr K.Y. Lim (Jeonju, Republic of Korea) for translation the name of the type locality of L. circularis from Korean. Dr S.I. Golovatch and Dr Ark.A. Schileyko (both Moscow, Russia) have kindly provided access to the holotype of $L$. variabilis housed at the ZMUM. My special thank is extended to Mr V.M. Kazarin (FSCB, Vladivostok, Russia) for the help in preparation of the scanning electron micrographs and Dr V.M. Loktionov (FSCB, Vladivostok, Russia) for the help in the preparation of some photographs (Fig. 1A-B) . Dr W.A. Shear (Hampden-Sydney, USA) kindly checked the English of an advanced draft.

\section{References}

Attems C. 1898. System der Polydesmiden, I. Denkschriften der Kaiserlichen Akademie der Wissenschaften Mathematisch-Naturwissenschaftliche Classe 67 (1): 221-482.

Attems C. 1904. Myriopoden. Fauna arctica 3 (1): 33-54.

Attems C. 1931. Die Familie Leptodesmidae und andere Polydesmiden. Zoologica, Stuttgart 30 (3/4): $1-149$

Attems C. 1938. Polydesmoidea II. Fams. Leptodesmidae, Oxydesmidae, Gomphodesmidae. Das Tierreich 69: 1-487. https://doi.org/10.1515/9783111430645-003

Chamberlin R.V. \& Wang Y.M. 1953. Records of millipeds (Diplopoda) from Japan and other Oriental areas, with descriptions of new genera and species. American Museum Novitates 1621: 1-3.

Ganin G.N. 1997. Soil Animals of the Ussuri Region. Dalnauka, Vladivostok/Khabarovsk. [In Russian, English summary.]

Ganin G.N. 2009. Hypothetical factors of origin and coexisting of closely related soil-dwelling species. In: Storozhenko S.Yu. (ed.) A.I. Kurentsov's Annual Memorial Meetings. Issue 20: 147-156. Dalnauka, Vladivostok. [In Russian.]

Ganin G.N. 2011. Structural and Functional Organization of Mezopedobiont Communities of the Southern Russian Far East. Dalnauka, Vladivostok. [In Russian.] 
Golovatch S.I. 1979. Notes on Levizonus thaumasius Att. (Diplopoda). In: Ivliev L.A. (ed.) Ekologiya $i$ biologiya chlenistonogikh yuga Dalnego Vostoka: 17-20. DVNC AN SSSR, Vladivostok. [In Russian.]

Gromyko M.N. 1990. Peculiarities in the structure of soil populations in oakwood ecosystems of the Sikhote-Alin Biosphere Reserve. In: Myslenkov A.I. (ed.) Ekologicheskie issledovaniya v SikhoteAlinskom zapovednike: 57-72. TSNIL Glavokhoty RSFSR, Moscow. [In Russian.].

Hoffman R.L. 1956. Studies on some Oriental xystodesmine millipeds. Proceedings of the Entomological Society of Washington 58 (2): 95-104.

Hoffman R.L. 1980. Classification of the Diplopoda. Muséum d'Histoire naturelle, Genève.

Jeekel C.A.W. 1971. Nomenclator generum et familiarum Diplopodorum; A list of the genus and family-group names in the Class Diplopoda from the $10^{\text {th }}$ edition of Linnaeus, 1758 , to the end of 1957. Monografieën van de Nederlandse Entomologische Vereniging 5: 1-412.

Korsós Z., Nakamura Ya. \& Tanabe T. 2011. Two new millipede species of the genus Riukiaria (Diplopoda, Polydesmida, Xystodesmidae) endemic to the Ryukyu Archipelago, Japan. Zootaxa 2877: 55-68. https://doi.org/10.11646/zootaxa.2877.1.3

Kraus O. 1960. Über 'Hokkaidaria hamuligera' Verhoeff nom. nud., eine Art des Genus Japonaria (Diplopoda, Leptodesmidae). Opuscula Zoologica 49: 1-3.

Kurcheva G.F. \& Mikhaljova E.V. 1980. Millipedes (Diplopoda) of some forest types of the Verkhne-Ussuriyskii Research Station. In: Rozenberg V.A. (ed.) Kompleksnye issledovaniya lesnykh biogeotsenozov: 117-127. DVNC AN SSSR, Vladivostok. [In Russian.]

Lokschina I.E. \& Golovatch S.I. 1977. The new myriapods (Diplopoda) from the USSR. Byulleten Moskovskogo obshchestva ispytateley prirodi, Biology 82 (1): 73-78. [In Russian.]

Lokšina I.E. \& Golovatch S.I. 1979. Diplopoda of the USSR fauna. Pedobiologia 19 (6): 381-389.

Marek P., Tanabe T. \& Sierwald P. 2014. A Species Catalog of the Millipede Family Xystodesmidae (Diplopoda: Polydesmida). Virginia Museum of Natural History, Martinsville, Virginia.

Mikhaljova E.V. 1978. On the fauna of Diplopoda in coniferous-broadleaved forests of the Ussuryskiy Nature Reserve. In: Suschenya L.M. \& Khotko E.I. (eds) Problemy pochvennoy zoologii: 157. Nauka i tekhnika, Minsk. [In Russian.]

Mikhaljova E.V. 1981a. The millipede genus Levizonus (Diplopoda, Xystodesmidae) from the USSR Far East. Byulleten Moskovskogo obshchestva ispytateley prirodi, Biology 86 (3): 62-67. [In Russian, English summary.]

Mikhaljova E.V. 1981b. Millipedes (Diplopoda) of broadleaved and broadleaved-pine forests of the Lazovskii Nature Reserve. In: Arefin V.S. \& Kulikova L.S. (eds) Fauna i ekologiya nasekomykh Primorskogo kraya i Kamchatki: 84-91. DVNC AN SSSR, Vladivostok. [In Russian.]

Mikhaljova E.V. 1983. Distribution of millipedes (Diplopoda) along the soil profile in the forests of the Primorskiy Province. In: Ivliev L.A. \& Kulikova L.S. (eds) Fauna i ekologiya chlenistonogikh Dalnego Vostoka: 77-90. DVNC AN SSSR, Vladivostok. [In Russian.]

Mikhaljova E.V. 1984. On the breeding of Levizonus thaumasius Att. (Diplopoda). In: Ghilarov M.S. (ed.) Problemy pochvennoy zoologhii. Abstracts, 8 All-Union Conference of Soil Zoology. Book 2: 14. Institut zoologii AN TSSP, Ashkhabad. [In Russian.]

Mikhaljova E.V. 1988. Millipedes (Diplopoda) of the Ussuriyskii and 'Kedrovaya Pad' nature reserves. In: Arefin V.S. (ed.) Rol nasekomykh v biotsenozakh Dalnego Vostoka: 68-74. DVO AN SSSR, Vladivostok. [In Russian.] 
Mikhaljova E.V. 1990. On the fauna of Diplopoda of the USSR Far East. Zoologicheskii Zhurnal 69 (5): 134-138. [In Russian, English summary.]

Mikhaljova E.V. 1993. The millipedes (Diplopoda) of Siberia and the Far East of Russia. Arthropoda Selecta 2 (2): 3-36.

Mikhaljova E.V. 1997. Review of the cavernicolous millipede fauna of the Far East of Russia, with description of a new troglophilic species (Diplopoda). Arthropoda Selecta 5(3/4): 143-149.

Mikhaljova E.V. 1998. The millipedes of the Far East of Russia (Diplopoda). Arthropoda Selecta 7 (1): $1-77$.

Mikhaljova E.V. 2002. A contribution to the millipede faunas of Korea and the Russian Far East. Arthropoda Selecta 10 (2): 147-150.

Mikhaljova E.V. 2004. The Millipedes (Diplopoda) of the Asian Part of Russia. Pensoft, Sofia/Moscow.

Mikhaljova E.V. 2009a. A list of the millipedes (Diplopoda) of the Russian Far East. Far Eastern Entomologist 197: 1-8.

Mikhaljova E.V. 2009b. The millipedes (Diplopoda) of the Russian Far East islands and the Kamchatka Peninsula. Soil Organisms 81 (3): 599-616.

Mikhaljova E.V. 2016. New species and new records of millipedes (Diplopoda) from the Asian part of Russia. Far Eastern Entomologist 316: 1-25.

Mikhaljova E.V. 2017. The Millipede Fauna (Diplopoda) of the Asian Part of Russia. Dalnauka, Vladivostok. [In Russian.]

Mikhaljova E.V. \& Bakurov V.D. 1989. On millipedes (Diplopoda) of the Siniy Mountain Ridge (Sikhote-Alin). In: Ryabinin N.A. (ed.) Pochvennye bespozvonochnye yuga Dalnego Vostoka: 38-47. DVO AN SSSR, Khabarovsk. [In Russian.]

Mikhaljova E.V. \& Korsós Z. 2003. Millipedes (Diplopoda) from Korea, the Russian Far East, and China in the collection of the Hungarian Natural History Museum. Acta Zoologica Hungarica 49 (3): $225-252$.

Mikhaljova E.V. \& Petukhova E.L. 1983. A comparative analysis of the millipede faunas (Diplopoda) of Primorskiy Province's forests with the help of inclusion and similarity indices. In: Semkin B.I. \& Sukhanov V.V. (eds) Teoretiko-grafovye metody v biogeograficheskikh issledovaniyakh: 48-66. DVNC AN SSSR, Vladivostok. [In Russian.]

Mikhaljova E.V., Golovatch S.I. \& Wytwer J. 2000. On some new or poorly-known millipedes (Diplopoda) from North Korea. Fragmenta Faunistica 43 (10): 109-122.

https://doi.org/10.3161/00159301FF2000.43.10.109

Minelli A. (ed.) 2015. The Myriapoda: Treatise on Zoology - Anatomy, Taxonomy, Biology. Brill, Leiden/Boston. https://doi.org/10.1163/9789004188273

Miyosi Y. 1959. Über japanische Diplopoden. Arachnological Society of East Asia, Osaka. [In Japanese, with German summary.]

Murakami Y. 1972. Some myriapods from Hokkaido, Northern Japan. Memoirs of the National Science Museum 5: 57-64.

Paik K.-Y. 1958. A list of Chilopoda, Symphila and Diplopoda from Korea. Kyungpook University, Theses Collection 2: 351-369.

Shelley R.M. 1993. The milliped genus Isaphe Cook (Polydesmida: Xystodesmidae). Canadian Journal of Zoology 71: 1161-1168. https://doi.org/10.1139/z93-158 
Shelley R.M. 2003. A revised, annotated, family-level classification of the Diplopoda. Arthropoda Selecta 11 (3): 187-207.

Shelley R.M., Sierwald P., Kiser S.B. \& Golovatch S.I. 2000. Nomenclator Generum et Familiarum Diplopodorum II. A List of the Genus and Family-Group Names in the Class Diplopoda from 1958 through 1999. Pensoft, Sofia/Moscow.

Takakuwa Y. 1941. Weitere japanische Lithobius-Arten und zwei neue Diplopoden. Transactions of the Sapporo Natural History Society 17 (1): 1-9.

Takakuwa Y. 1942. Zur Kenntnis der Japanischen Diplopoden. Annotationes Zoologicae Japonenses 21: $39-47$.

Takakuwa Y. 1954. Diplopoden aus Japan und ihn angrenzenden Gebieten. Japan Society for the Promotion of Science, Tokyo. [In Japanese.]

Tanabe T. 1992. Karyotypes of four Xystodesmid millipeds from Japan. Acta Arachnologica 41 (1): 87-90. https://doi.org/10.2476/asjaa.41.87

Tanabe T. 1994. The millipede genus Levizonus (Polydesmida, Xystodesmidae) in Japan. Japanese Journal of Entomology 62 (1): 101-113.

Tanabe T. 2002. Revision of the millipede genus Parafontaria Verhoeff, 1936 (Diplopoda, Xystodesmidae). Journal of Natural History 36: 2139-2183.

https://doi.org/10.1080/00222930110085610

Tanabe T. \& Shinohara K. 1996. Revision of the millipede genus Xystodesmus, with reference to the status of the tribe Xystodesmini (Diplopoda: Xystodesmidae). Journal of Natural History 30: 14591449. https://doi.org/10.1080/00222939600770831

Tanabe T. \& Sota T. 2014. Both male and female novel traits promote the correlated evolution of genitalia between the sexes in an arthropod. Evolution 68 (2): 441-452. https://doi.org/10.1111/evo.12288

Verhoeff K.W. 1936. Über Diplopoden aus Japan, gesammelt von Herrn Y. Takakuwa. Transactions of the Sapporo Natural History Society 14 (3): 148-172.

Verhoeff K.W. 1941. Über Gruppen der Leptodesmiden und neues System der Ordo Polydesmoidea. Archiv für Naturgeschichte 10 (3): 399-415.

Manuscript received: 24 July 2020

Manuscript accepted: 3 March 2021

Published on: 10 June 2021

Topic editors: Rudy C.A.M. Jocqué \& Nesrine Akkari

Desk editor: Charlotte Gérard

Printed versions of all papers are also deposited in the libraries of the institutes that are members of the EJT consortium: Muséum national d'Histoire naturelle, Paris, France; Meise Botanic Garden, Belgium; Royal Museum for Central Africa, Tervuren, Belgium; Royal Belgian Institute of Natural Sciences, Brussels, Belgium; Natural History Museum of Denmark, Copenhagen, Denmark; Naturalis Biodiversity Center, Leiden, the Netherlands; Museo Nacional de Ciencias Naturales-CSIC, Madrid, Spain; Real Jardín Botánico de Madrid CSIC, Spain; Zoological Research Museum Alexander Koenig, Bonn, Germany; National Museum, Prague, Czech Republic. 